RESEARCH PAPER RP1322

Part of Journal of Research of the National Bureau of Standards, Volume 25,

August 1940

\title{
EFFECT OF RATE OF HEATING THROUGH THE TRANS- FORMATION RANGE ON AUSTENITIC GRAIN SIZE
}

\author{
By Samuel J. Rosenberg and Thomas G. Digges
}

Data are presented to show how the rate of heating through the transformation range affects the austenitic grain size at various temperatures of high-purity alloys of iron and carbon and commercial and experimental plain carbon steels. The commercial steels included heats produced under furnace practice that resulted in both controlled and noncontrolled grain size. In certain cases, the austenitic grain size of these alloys and steels was affected by the rate of heating through the transformation range, but all the materials did not respond in the same manner.

CONTENTS

Page

I. Introduction

II. Previous investigations _.

III. Equipment and procedure

IV. Materials _._.

1. High-purity alloys of iron and carbon

2. Commercial plain carbon steels _ _ _

3. Experimental plain carbon steels

V. Results _.

1. High-purity alloys of iron and carbon

2. Commercial plain carbon steels $\ldots \ldots$

3. Experimental plain carbon steels $\ldots \ldots \ldots 26$

VI. Summary

\section{INTRODUCTION}

The influence of austenitic grain size on many properties of steel has been widely discussed during the past decade and is now generally recognized. Not so much attention has been paid, however, to the study of factors which influence the austenitic grain size. Probably this has been due, at least in part, to the belief that a steel, once made, had what was termed an "inherent" grain size. The word "inherent" denotes unchanging, and its unfortunate use conveyed the idea to many that at any selected temperature a particular steel had a definite grain size and that this remained fixed regardless of other factors.

In a previous study of the influence of austenitic grain size on the hardenability of high-purity iron-carbon alloys [1], ${ }^{1}$ it was observed that the rate of heating through the transformation range often had a pronounced influence on the final austenitic grain size. If steels are similarly affected, this factor deserves consideration. This becomes especially important when consideration is given to the wide range

\footnotetext{
${ }_{1}^{1}$ Figures in brackets indicate the literature references at the end of this paper.
} 
in heating rates commercially employed, varying from the extremely rapid heating secured in induction hardening to the slow rates obtained with furnace heating of large parts.

The present study was made to show the effect of the rate of heating to different temperatures on the austenitic grain size of highpurity alloys of iron and carbon and of commercial plain carbon steels, with a wide range in carbon content. The commercial steels also differed in the method of deoxidation. The effects of other factors that influence the austenitic grain size, such as initial structure, amount of hot and cold working, time at maximum temperature, etc., were not investigated.

\section{PREVIOUS INVESTIGATIONS}

Excellent reviews of our knowledge concerning grain size have been given by Ward and Dorn [2] and by Shapiro [3]. The review by Ward and Dorn in particular contains an extensive bibliography.

Although these reviews reveal a wealth of information relating to the effect of austenitic grain size upon the properties of steel, very few data, aside from the effect of furnace practice, are available to indicate the effect of other variables upon the grain size, and these data are frequently contradictory. This is especially true with regard to the effect of the rate of heating.

Grossmann [4] found that different rates of heating had no effect upon the McQuaid-Ehn grain size of a 0.17-percent-carbon steel carburized at $1,700^{\circ} \mathrm{F}$ for 2 hours. Three samples were tested. The time of heating from room temperature to carburizing temperature was approximately $2 \frac{1}{2}$ hours, 30 minutes, and 5 minutes. All specimens had the same McQuaid-Ehn grain size (ASTM grain No. 5).

Digges and Jordan [5], in their investigation of the hardening characteristics of 1-percent-carbon tool steels (having "controlled" and "noncontrolled" grain sizes), studied the effect of the rate of heating upon the austenitic grain size in an indirect manner. Their work was concerned primarily with the depth of hardening obtained in $3 / 4$-inch round specimens quenched from $1,425^{\circ}$ and $1,550^{\circ} \mathrm{F}$. With all other factors constant, the depth of hardening was influenced by the grain size at the time of quenching, a coarser austenitic grain being reflected in greater depth of hardening. Variations, from 1 to 13 minutes, in the time required for the center of the $\% / 4$-inch rounds to reach the hardening temperatures had no significant influence on the depth of hardening of the two steels.

The effect of the rate of heating upon the austenitic grain size of 0.80 -percent-carbon steel was studied by Tobin and Kenyon [6]. Specimens about 0.05 inch thick were heated at rates of 1.12 and 800 degrees $\mathrm{F} / \mathrm{min}$ through the interval of $1,300^{\circ}$ to $1,400^{\circ} \mathrm{F}$, which included the critical temperature. They were then held at $1,400^{\circ} \mathrm{F}$ for 1 hour, after which all of the specimens had an ASTM No. 6 grain size. This procedure was repeated at $1,500^{\circ} \mathrm{F}$. All specimens again were found to have the same grain size, which in this case was designated by Tobin and Kenyon as No. 51/2. "Thus," they concluded, "the austenitic grain size of this steel was independent of the investigated rates of heating through the critical."

Herty, McBride, and Hough [7] studied the effect of the rate of heating through the transformation range on the grain size of a 
0.33-percent-carbon steel deoxidized with silicon and a 0.41 -percentcarbon steel deoxidized with aluminum. Half-inch cubes were heated at $1,830^{\circ} \mathrm{F}$ for 1 hour in order to produce a coarse-grained structure, air-cooled, and then heated through the transformation range at various rates to $1,520^{\circ} \mathrm{F}$. The following data show the influence of heating rate upon the originally coarse-grained structure (3.3 grains/in. ${ }^{2}$ at $\left.\times 100\right)$ of the "silicon-killed" steel.

\begin{tabular}{|c|c|}
$\begin{array}{c}\text { Rate of heat- } \\
\text { ing }\end{array}$ & $\begin{array}{c}\text { Grains/in. }{ }^{2} \text { at } \\
\times 100\end{array}$ \\
\cline { 1 - 2 } Degrees F/min. & \\
2.0 & \\
4.0 & 368 \\
5.6 & 164 \\
8.5 & 25 \\
11.0 & 7.6 \\
12.6 & 8.4 \\
18.0 & 6.4 \\
& 6.0 \\
\hline
\end{tabular}

When a $1 / 4$-inch cube of this steel in the coarse-grained condition was placed in the furnace at $1,520^{\circ} \mathrm{F}$ and removed 5 minutes after it had come to the temperature of the furnace, no grain refinement could be observed. The same experiments were made on the aluminumtreated steel, having initially a coarse-grained structure. At all heating rates an extremely fine grain was formed, about 200 grains per square inch at $\times 100$.

In the present report the term "grain size" will be used to denote the grain size of the austenite established at the maximum temperatures.

\section{EQUIPMENT AND PROCEDURE}

To insure adequate control of the rate of heating between extremely wide limits, it was necessary to use small specimens, approximately 0.1 inch square by about 0.04 inch thick. The specimens were heated in vacuo except when a lead bath was utilized to obtain maximum rates of heating. Specimens heated in vacuo were suspended from a 32-gage Chromel-Alumel thermocouple. One wire of the thermocouple was spot-welded to the center of the flat face of the specimen, and the other wire was spot-welded to the center of the opposite face. The specimen was located within the heating chamber in the center of a Chromel heating coil, one-fourth inch in diameter by one-half inch long. This heating chamber has been described in detail by Digges [1].

As a measure of the rate of heating, the time to heat from $1,325^{\circ}$ to $1,450^{\circ} \mathrm{F}$ was used. This temperature interval included the $A c_{1}$ and $A c_{3}$ points $\left(1,340^{\circ}\right.$ and $1,425^{\circ} \mathrm{F}$, respectively) in 0.50 -percentcarbon steel, the material on which the first tests were made. In some of the high-carbon alloys, the $A c_{c m}$ point occurred at a higher temperature than $1,450^{\circ} \mathrm{F}$, but it was believed that the rate of heating through this point would not be significant in comparison with the rate through the $A c_{1-2-3}$ transformation.

In conducting the tests in vacuo, the specimens were heated rather rapidly to a temperature somewhat below $1,325^{\circ} \mathrm{F}$, then at the desired rate through the range $1,325^{\circ}$ to $1,450^{\circ} \mathrm{F}$, and then again 
rapidly to the required temperature. For the fastest rates of heating, specimens were plunged into a lead bath maintained at the desired temperature. With the small specimen used, an extremely rapid rate of heating (practically instantaneous) through the temperature range $1,325^{\circ}$ to $1,450^{\circ} \mathrm{F}$ was obtained in the lead bath. All specimens were held at the maximum temperature for 15 minutes and then cooled in a manner suitable for outlining the austenitic grains with a proeutectoid constituent.

After preparing the specimens for microscopic examination, grain counts were made by two observers, usually at four different locations. Grain counts were made in a circle which was 7.75 square inches in area and when possible were made at a magnification of 100 diameters. Fine-grained steels were counted at higher magnifications. Since actual grain counts on steels having a decidedly mixed grain size are meaningless, in these cases the relative amounts of the predominating grain sizes were estimated according to the grain-size classification of the American Society for Testing Materials, which is given in table 1

TABLE 1.-Grain size corresponding to American Society for Testing Materials Index Numbers

\begin{tabular}{|c|r|r|}
\hline \multirow{2}{*}{$\begin{array}{c}\text { ASTM. grain size } \\
\text { number }\end{array}$} & \multicolumn{2}{|c|}{$\begin{array}{c}\text { Number of grains per } \\
\text { square inch at } \times 100\end{array}$} \\
\cline { 2 - 3 } & Minimum & Maximum \\
\hline & $3 / 4$ & $11 / 2$ \\
\hline 2 & $11 / 2$ & 3 \\
\hline 3 & 6 & 6 \\
5 & 12 & 12 \\
6 & 24 & 48 \\
7 & 48 & 96 \\
\hline & 96 & 192 \\
\hline
\end{tabular}

In theory the delineation of austenitic grains is simple. A steel need only be heated to the required temperature and cooled so as to reject a proeutectoid constituent to the austenitic grain boundaries which, after suitable etching, are revealed by microscopic examination at room temperature.

This procedure, however, is somewhat difficult for small specimens of hypoeutectoid steels. In order to outline the grains properly, the specimen must be cooled at exactly the right rate. Too fast a rate of cooling does not allow the precipitation of sufficient ferrite to definitely outline all the grains. A grain count on such a specimen is usually low, that is, the grains appear to be coarser than they actually are. Too slow a rate of cooling results in the precipitation of too much ferrite, accompanied by coalescence of the ferrite and obliteration of the outline of the original austenitic grains. The result of a grain count on such a specimen usually is high, that is, the grains appear to be finer than they actually are.

With hypereutectoid steels, containing at least 1 percent of carbon, it is not difficult to outline the grains at temperatures sufficiently high to dissolve the cementite completely. At the lower temperatures used for hardening these steels, however, the excess cementite tends to spheroidize and on cooling is not precipitated solely at the boundaries of the parent austenite grains. 

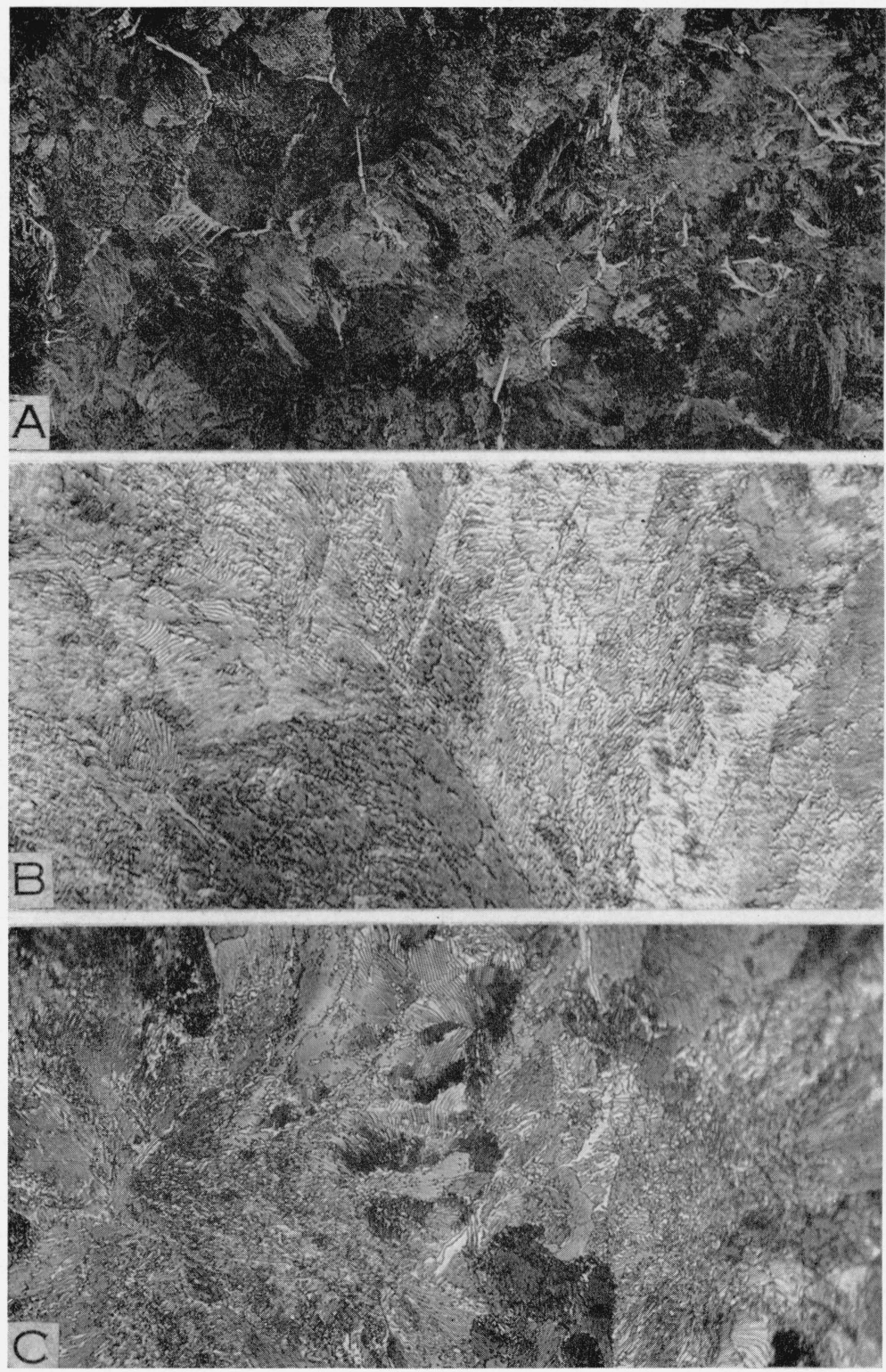

Figure 1.-Initial structure of iron-carbon alloys.

$A, 0.50$ percent of carbon $(H P-1) ; \times 100 . \quad B, 1.01$ percent of carbon $(H P-2) ; \times 500 . \quad C, 1.21$ percent of carbon $(H P-S) ; \times 500$. Etched with 1-percent nital. 

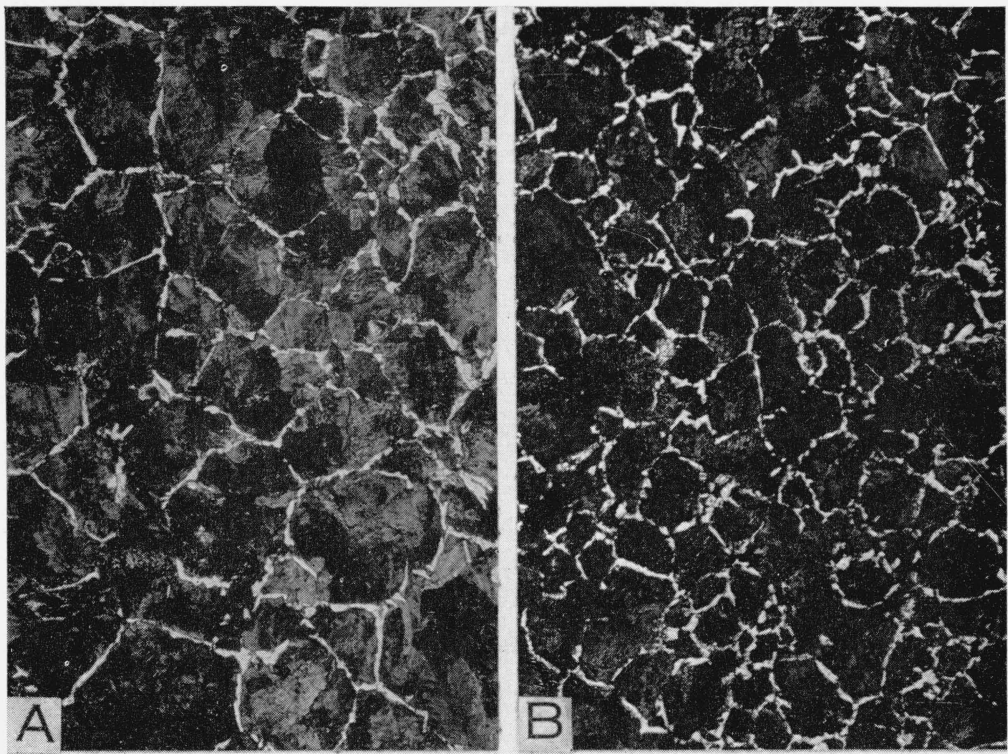

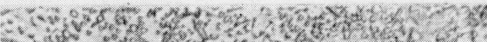
-25y $5 \rightarrow 003$ X.s.

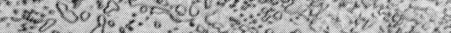

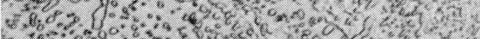
7. 30000 . * 7 , * 32 के

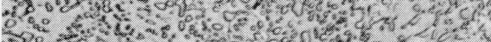

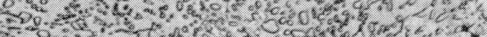

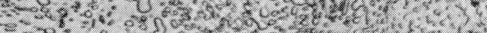

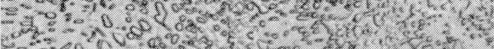
8.

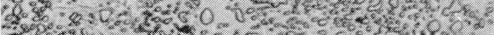

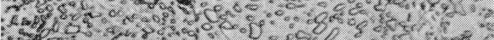
to. 1 3 54.

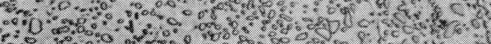
F. $890 \%$. 80 \%

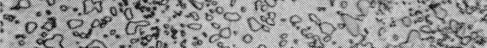

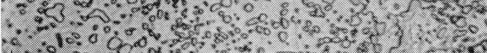
40100400 \% 28. $C$ is

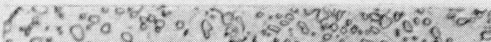

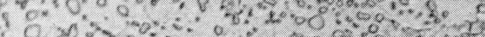

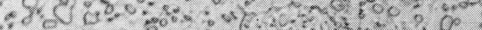

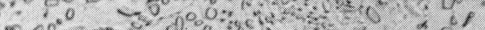

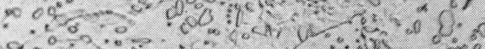

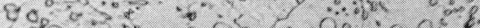

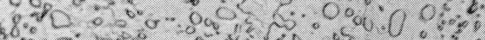
हैष्:

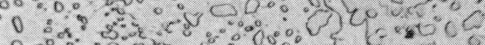

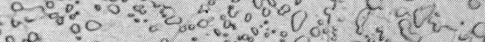

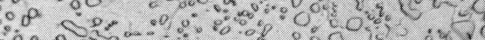

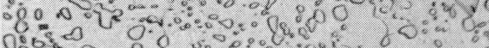

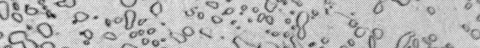

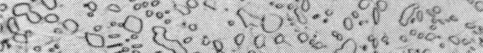

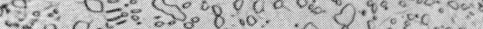

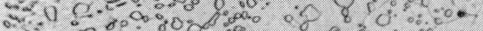

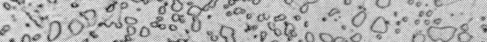

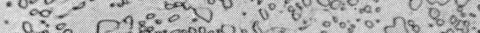

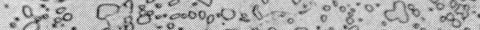

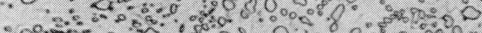

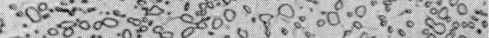

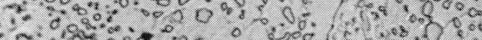

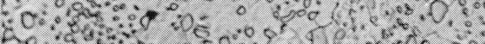

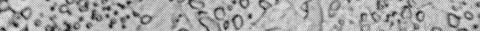

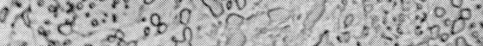
D.3. 300 a

FIGURE 2.-Initial structure of commercial plain carbon steels.

$A, 0.49$ percent of carbon $(C-1): \times 100 . \quad B, 0.49$ percent of carbon $(C-2) ; \times 100 . \quad C, 1.05$ percent of carbon $(C-3) ; \times 500 . \quad D, 1.06$ percent of carbon $(C-4) ; \times 500$. Etched with 1-percent nital. 

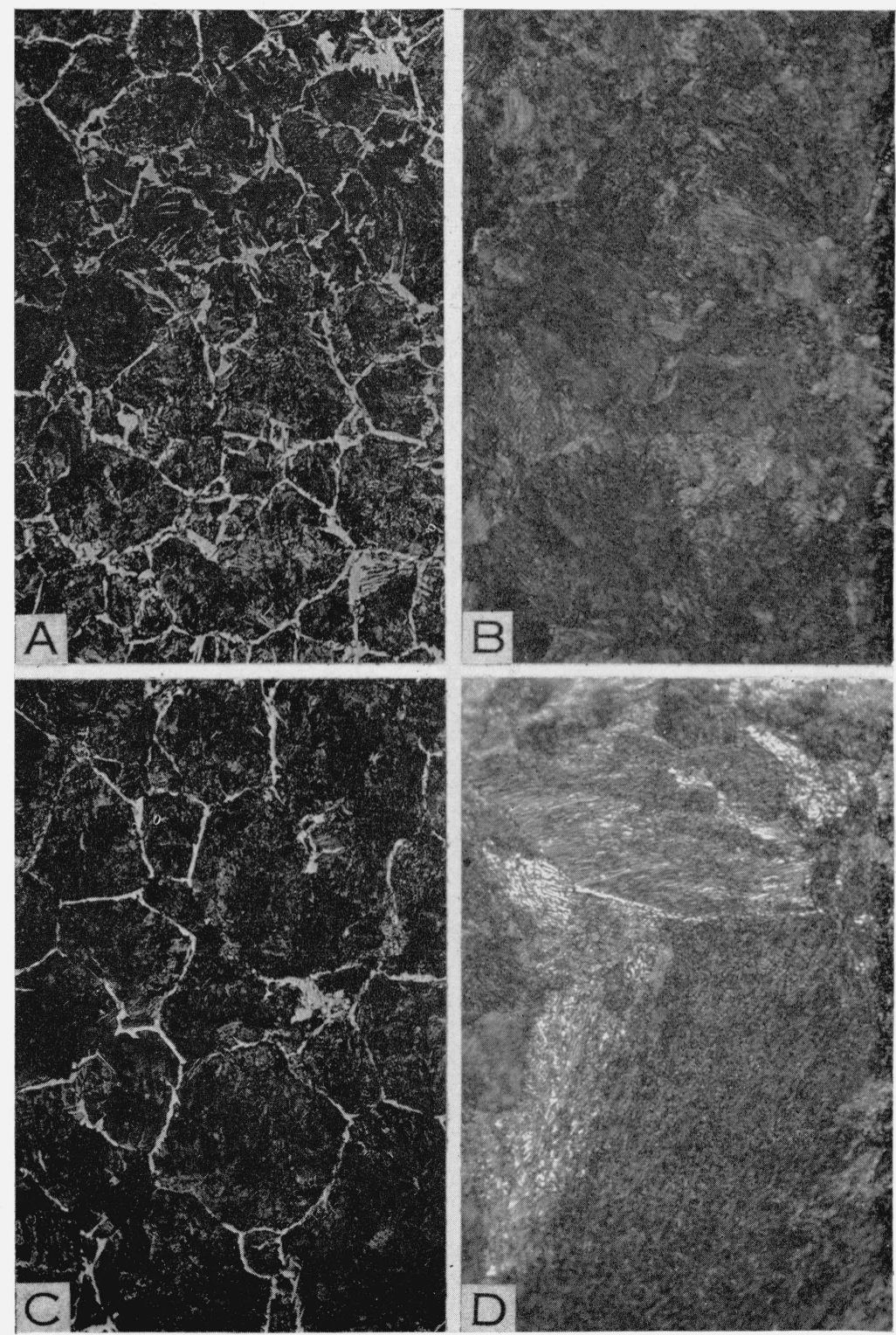

FIGURE 3.-Initial structure of experimental plain carbon steels.

$A, 0.48$ percent of carbon $(P C-1) ; \times 100 . \quad B, 1.12$ percent of carbon $(P C-2) ; \times 500 . \quad C, 0.57$ percent of carbon $(G C-1) ; \times 100 . \quad D, 1.02$ percent of carbon $(G C-2) ; \times 500$. Etched with 1-percent nital. 


\section{MATERIALS}

\section{HIGH-PURITY ALLOYS OF IRON AND CARBON}

The iron-carbon alloys used in the present study were the same as those used in previous investigations, and their preparation has been described in a previous report [8]. Essentially, the preparation consisted in carburizing hot- and cold-worked specimens of vacuummelted electrolytic iron in a mixture of hydrogen and benzene vapor, and subsequently homogenizing by heating in vacuo at $1,700^{\circ} \mathrm{F}$. Cooling from the temperature used in homogenizing was sufficiently rapid to produce sorbite (fine pearlite) in all the alloys. Specimens used for the determination of grain size had an initial structure of sorbite, as shown in figure 1.

Results of spectrochemical and chemical analyses and the determination of the gas content by the vacuum-fusion method showed that sulfur, nickel, cobalt, and oxygen were the major impurities in the alloys. These elements amounted to about 0.021 percent, whereas the total percentage (by weight) of all impurities determined was about 0.030 . The compositions of the alloys are given in table 2 .

\section{COMMERCIAL PLAIN CARBON STEELS}

Commercial plain carbon steels containing approximately 0.5 and 1 percent of carbon were used. Two heats containing 0.5 percent of carbon were furnished through the courtesy of a large producer, and two heats of tool steel containing 1 percent of carbon were purchased through regular channels of supply. As shown in table 2, the most significant difference in the chemical compositions of the hypoeutectoid steels was in the content of aluminum and of aluminum oxide. Similarly, the hypereutectoid steels differed in the proportions of aluminum and aluminum oxide. The heats containing appreciably higher proportions of metallic aluminum (that soluble in acid) and aluminum oxide were produced under conditions intended to control the austenitic grain size; the heats of relatively low total aluminum content were produced under conditions which resulted in noncontrol of austenitic grain size. All heats were representative of good commercial open-hearth practice. For the determination of grain size, specimens of the hypoeutectoid steels were used in the hot-rolled condition, with an initial structure of sorbite and ferrite (fig. 2, $A$ and $B)$. The hypereutectoid steels were annealed to produce an initial structure of spheroidized cementite (fig. 2, $C$ and $D$ ).

\section{EXPERIMENTAL PLAIN CARBON STEELS}

Two series of carbon steels were prepared from specimens cut from a forging of a plain carbon steel, which contained 0.20 percent of carbon and appreciable amounts of aluminum. The first series was prepared by pack-carburizing these specimens in a mixture of approximately 85 percent of wood charcoal and 15 percent of barium carbonate at $1,700^{\circ} \mathrm{F}$ for various periods of time. The carburized specimens were homogenized by pack-annealing at $1,700^{\circ} \mathrm{F}$ for 4 to 5 hours before normalizing from the usually recommended temperature range. The second series was prepared by carburizing specimens in hydrogen-benzene vapor at $1,700^{\circ} \mathrm{F}$ and subsequently homogenizing 
TABLE 2.-Chemical composition (percentage by weight) of materials used

\begin{tabular}{|c|c|c|c|c|c|c|c|c|c|c|c|c|c|c|c|c|}
\hline Identification & $\mathrm{C}$ & Mn & $\mathrm{P}$ & $\mathrm{S}$ & $\mathrm{Si}$ & $\mathrm{Cr}$ & $\mathrm{Ni}$ & $\mathrm{Co}$ & Mo & $\mathrm{V}$ & $\mathrm{Al}_{2} \mathrm{O}_{3}$ & $\begin{array}{l}\text { Acid-sol- } \\
\text { uble Al }\end{array}$ & $\begin{array}{c}\text { Total } \\
\text { Al }\end{array}$ & $\mathrm{H}_{2}$ & $\mathrm{O}_{2}$ & $\mathrm{~N}_{2}$ \\
\hline \multicolumn{17}{|c|}{ HIGH-PURITY ALLOYS OF IRON AND CARBON } \\
\hline $\begin{array}{l}H P-1 \\
H P-2 \\
H P-3\end{array}$ & $\begin{array}{l}0.50 \\
1.01 \\
1.21\end{array}$ & $\begin{array}{r}0.002 \\
.002 \\
.002\end{array}$ & $\begin{array}{l}<0.001 \\
<.001 \\
<.001\end{array}$ & $\begin{array}{r}0.004 \\
.004 \\
.004\end{array}$ & $\begin{array}{r}0.002 \\
.002 \\
.002\end{array}$ & -1 & $\begin{array}{r}0.007 \\
.007 \\
.007\end{array}$ & $\begin{array}{l}0.007 \\
.007 \\
.007\end{array}$ & & -1 & - n & $\mid-1-1-1-1$ & $|-1-1 \cdot|$ & $\begin{array}{r}0.0002 \\
.0002 \\
.0002 \\
\end{array}$ & $\begin{array}{r}0.003 \\
.003 \\
.003\end{array}$ & $\begin{array}{r}0.001 \\
.001 \\
.001\end{array}$ \\
\hline \multicolumn{17}{|c|}{ COMMERCIAL STEELS } \\
\hline $\begin{array}{l}C-1 \\
C-2 \\
C-8 \\
C-4\end{array}$ & $\begin{array}{l}0.49 \\
.49 \\
1.05 \\
1.06\end{array}$ & $\begin{array}{l}0.79 \\
.80 \\
.28 \\
.26\end{array}$ & $\begin{array}{r}0.023 \\
.022 \\
.019 \\
.013\end{array}$ & $\begin{array}{r}0.023 \\
.028 \\
.013 \\
.011\end{array}$ & $\begin{array}{r}0.22 \\
.21 \\
.22 \\
.19\end{array}$ & $\begin{array}{r}0.08 \\
.09\end{array}$ & $\begin{array}{r}.13 \\
.10\end{array}$ & 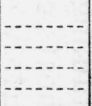 & $<0.01$ & $<0.01$ & $\begin{array}{r}0.001 \\
.007 \\
.006 \\
.010\end{array}$ & $\begin{array}{r}0.002 \\
.016 \\
.001 \\
.008\end{array}$ & $\begin{array}{l}0.0025 \\
.0195 \\
.004 \\
.013\end{array}$ & $\begin{array}{l}0.0002 \\
.0002 \\
.0002 \\
.0003\end{array}$ & $\begin{array}{r}0.004 \\
.003 \\
.007 \\
.009\end{array}$ & $\begin{array}{l}0.004 \\
.004 \\
.009 \\
.007\end{array}$ \\
\hline \multicolumn{17}{|c|}{ EXPERIMENTAL STEELS (PACK-CARBURIZED) } \\
\hline $\begin{array}{l}P C-1 \\
P C-2\end{array}$ & $\begin{array}{l}0.48 \\
1.12\end{array}$ & $\begin{array}{r}0.46 \\
.46\end{array}$ & $\begin{array}{r}0.043 \\
.043\end{array}$ & $\begin{array}{r}0.025 \\
.025\end{array}$ & $\begin{array}{r}0.15 \\
.15\end{array}$ & $\begin{array}{r}0.02 \\
.02\end{array}$ & $\begin{array}{r}0.011 \\
.011\end{array}$ & & & $\begin{array}{l}\text { Trace } \\
\text { Trace }\end{array}$ & $\begin{array}{r}0.017 \\
.017\end{array}$ & $\begin{array}{r}0.006 \\
.006\end{array}$ & $\begin{array}{r}0.015 \\
.015\end{array}$ & & & \\
\hline \multicolumn{17}{|c|}{ EXPERIMENTAL STEELS (GAS-CARBURIZED) } \\
\hline$G C-1$ & $\begin{array}{l}0.57 \\
1.02\end{array}$ & $\begin{array}{r}0.46 \\
.46\end{array}$ & $\begin{array}{r}0.043 \\
.043\end{array}$ & $\begin{array}{r}0.025 \\
.025\end{array}$ & $\begin{array}{r}0.15 \\
.15\end{array}$ & $\begin{array}{r}0.02 \\
.02\end{array}$ & $\begin{array}{r}0.011 \\
.011\end{array}$ & & $\mid-1+$ & $\begin{array}{l}\text { Trace } \\
\text { Trace }\end{array}$ & $\begin{array}{r}0.017 \\
.017\end{array}$ & $\begin{array}{r}0.006 \\
.006\end{array}$ & $\begin{array}{r}0.015 \\
.015\end{array}$ & & & \\
\hline
\end{tabular}



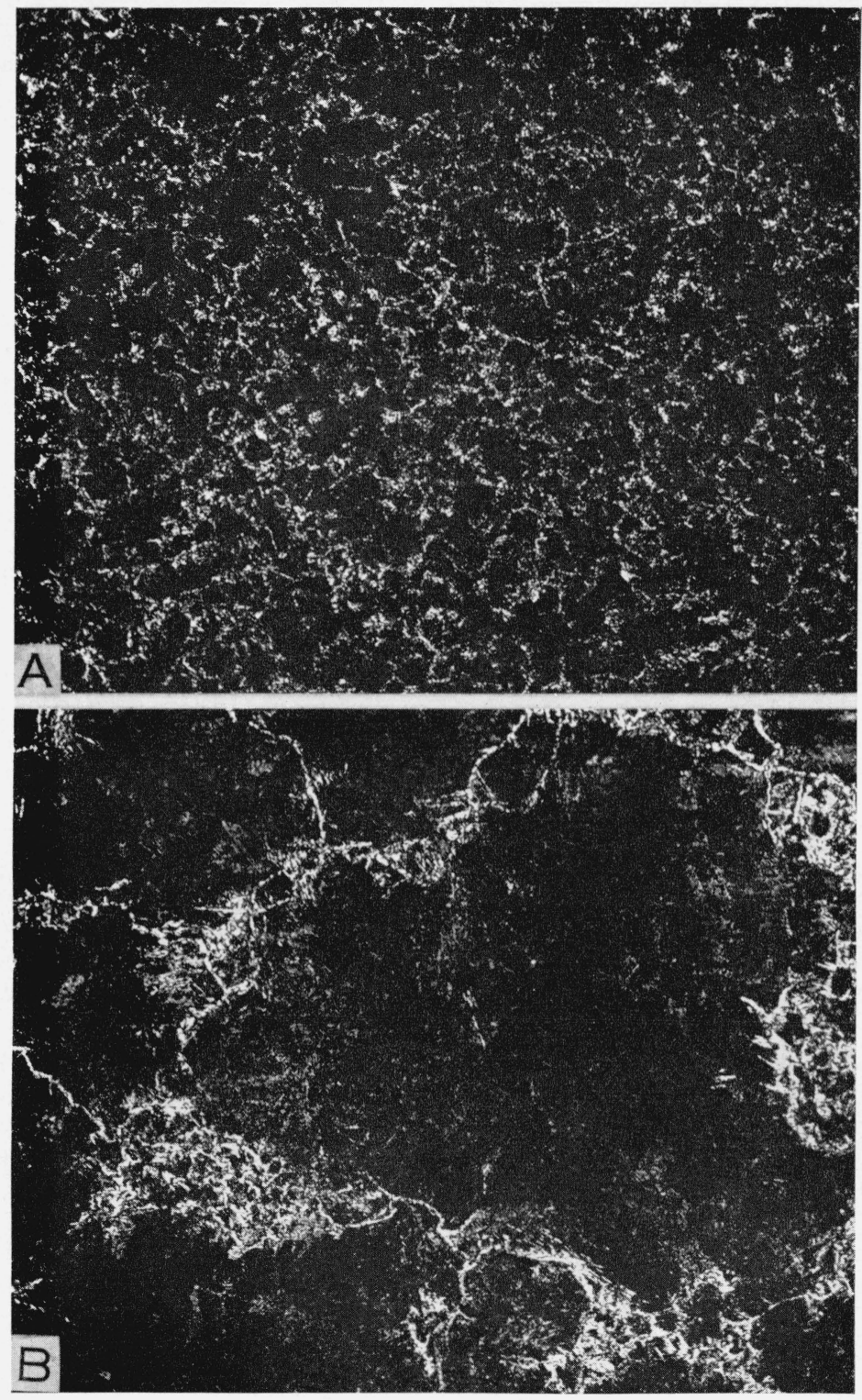

FIGURE 4.-Grain size at $1,475^{\circ} F$ of iron-carbon alloy $H P-1$ (0.50 percent of carbon).

$A$, Heated in lead bath; estimated ASTM grain No. 7. B, Heated 7.7 degrees F per minute; estimated ASTM grain No, -2 to 1; grains not outlined in approximately 20 percent of the area, which consisted of coalesced ferrite and pearlite. Etched with 1-percent nital. $\times 100$. 

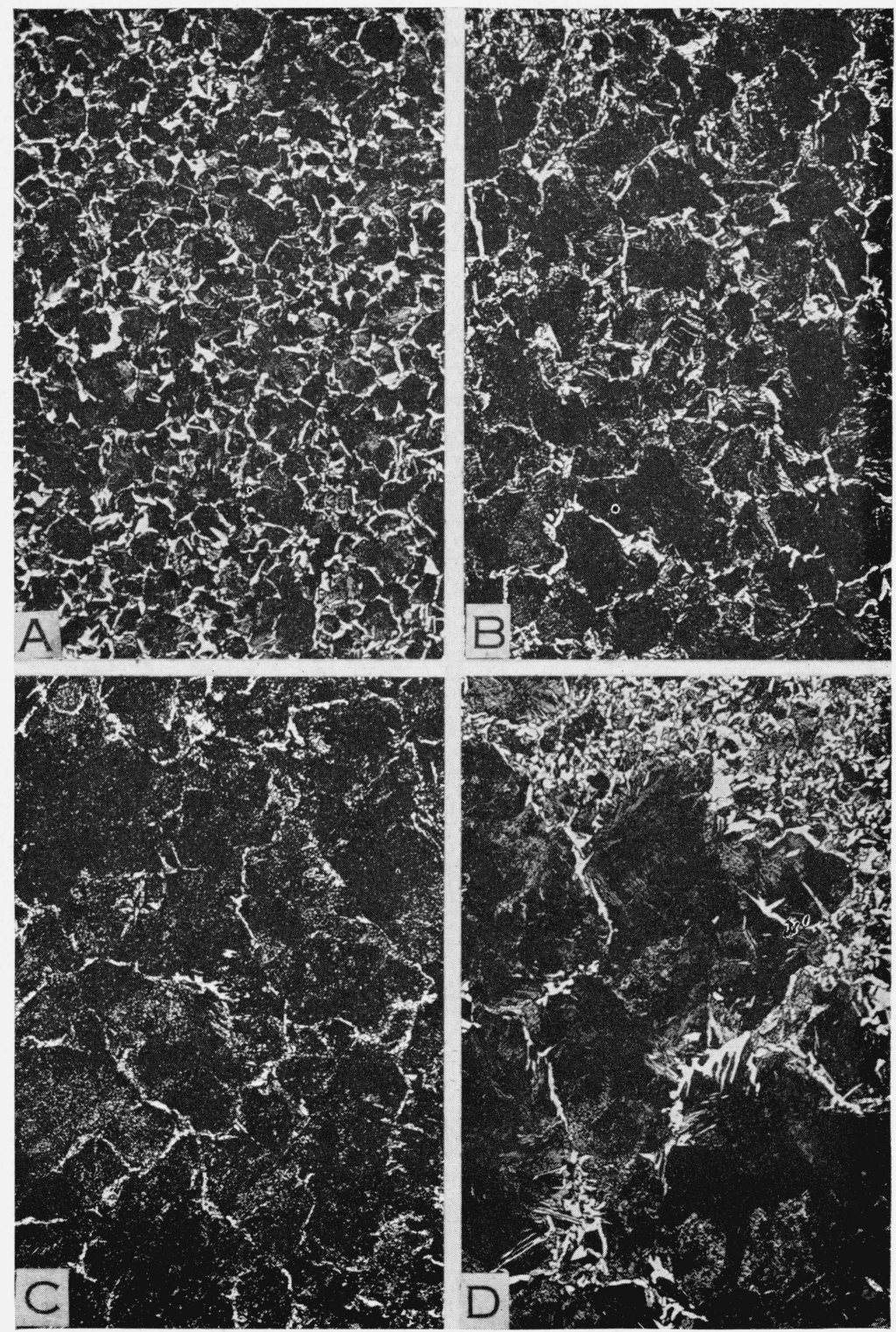

Figure 5.-Grain size at $1,500^{\circ} F$ of iron-carbon alloy HP-1 (0.50 percent of carbon).

$A$, Heated in lead bath; 35 grains per square inch at $\times 100 . \quad B$, Heated 440 degrees $\mathrm{F}$ per minute; 12 grains per square inch at $\times 100$. $C$, Heated 155 degrees $\mathrm{F}$ per minute; 4.4 grains per square inch at $\times 100$. $D$, Heated 13 degrees F per minute; estimated ASTM grain No. 1 or larger; grains not outlined in approximately 30 percent of the area, which consisted of coalesced ferrite and pearlite. Etched with 1-percent nital. $\times 100$. 


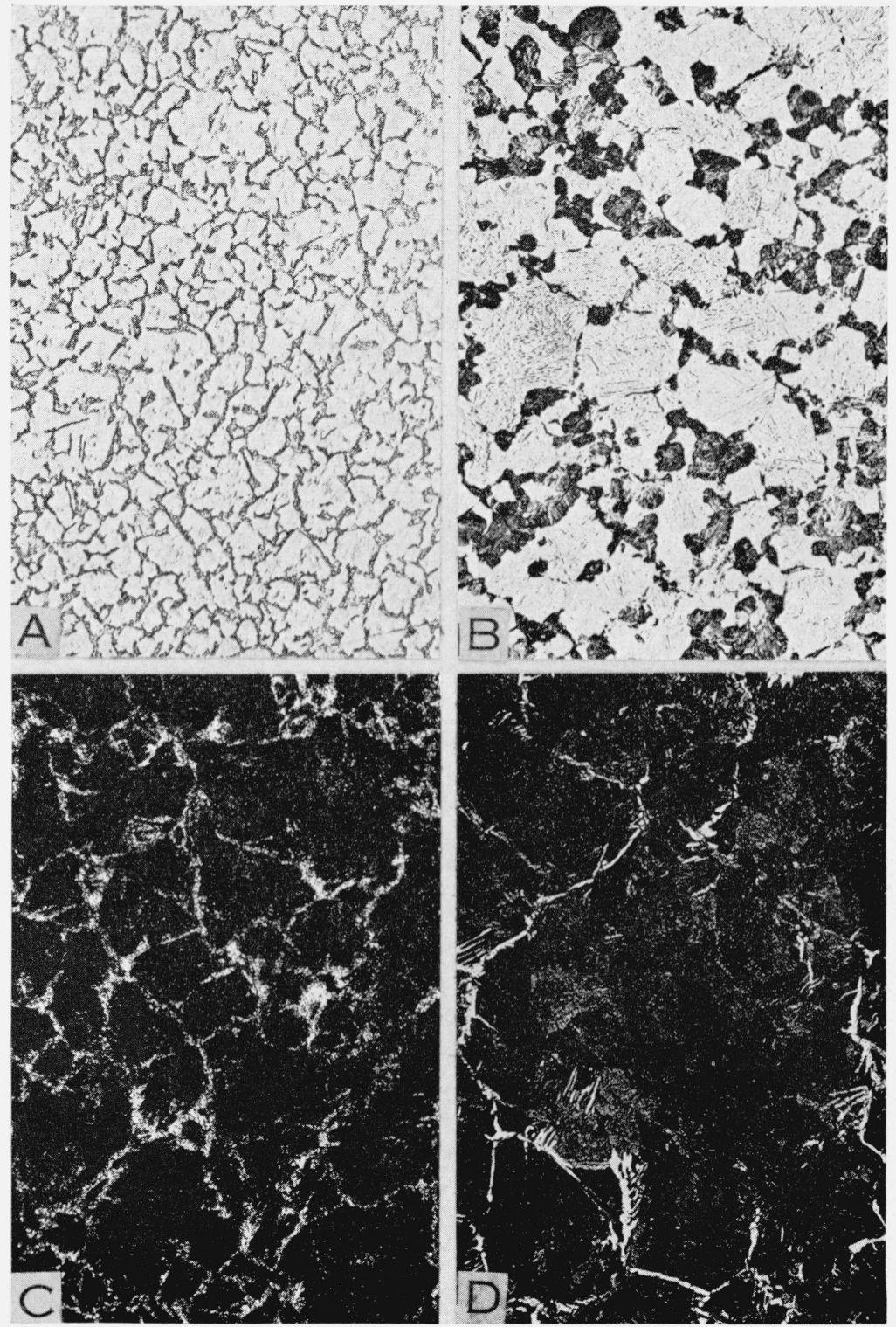

FiguRE 6.-Grain size at $1,600^{\circ} F$ of iron-carbon alloy $H P-1$ (0.50 percent of carbon).

$A$, Heated in lead bath; 50 grains per square inch at $\times 100 . \quad B$, Heated 940 degrees $\mathrm{F}$ per minute; 12 grains

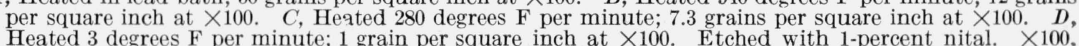



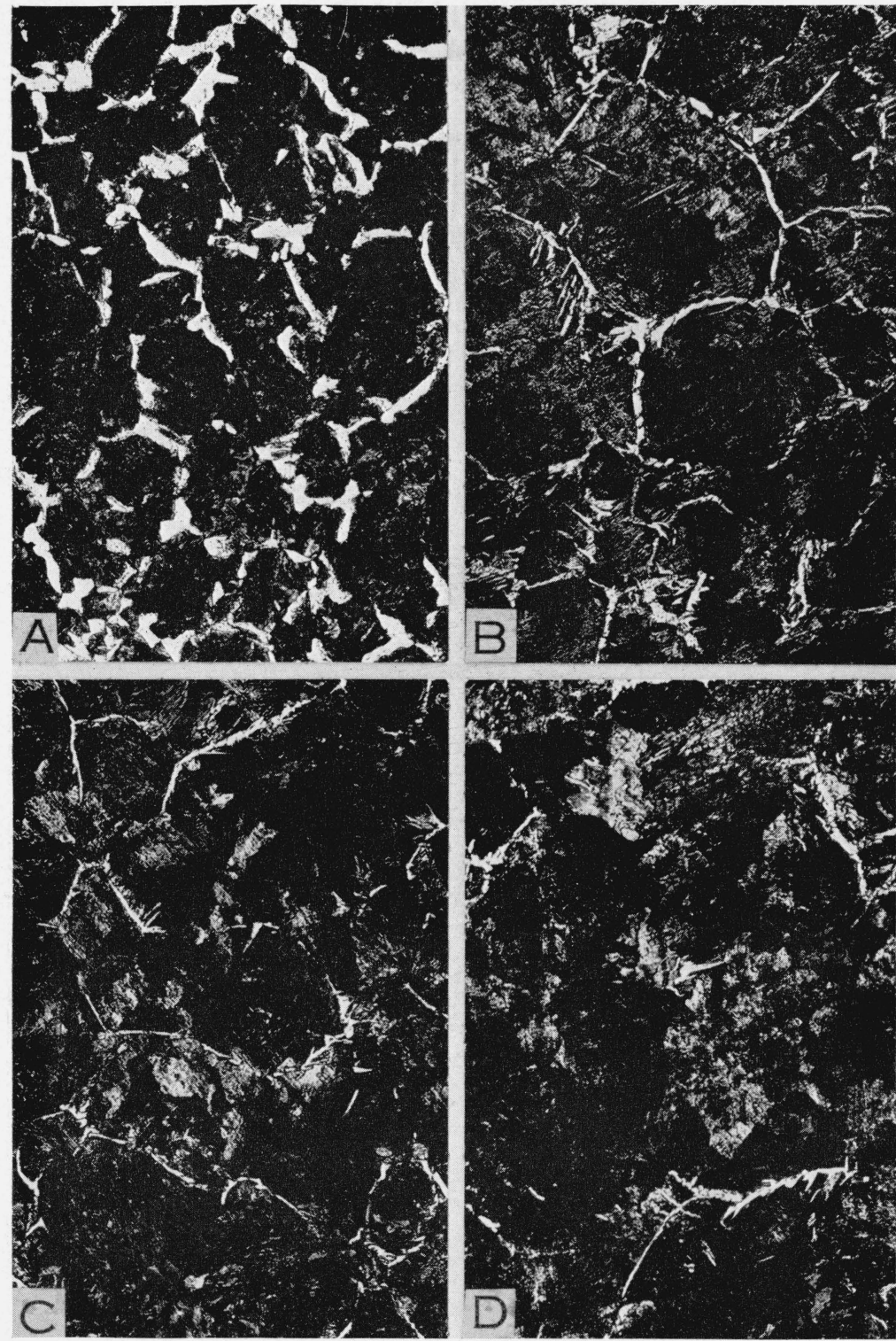

FiguRe 7.-Grain size at $1,800^{\circ} F$ of iron-carbon alloy $H P-1$ (0.50 percent of carbon).

$A$, Heated in lead bath; 5.4 grains per square inch at $\times 100 . \quad B$, Heated 575 degrees $\mathrm{F}$ per minute; 3.3 grains per square inch at $\times 100 . \quad C$, Heated 11 degrees $\mathrm{F}$ per minute; estimated ASTM grain No. 2 . $D$, Heated 3 degrees $\mathrm{F}$ per minute; 1 grain per square inch at $\times 100$. Etched with 1 -percent nital. $\times 100$. 


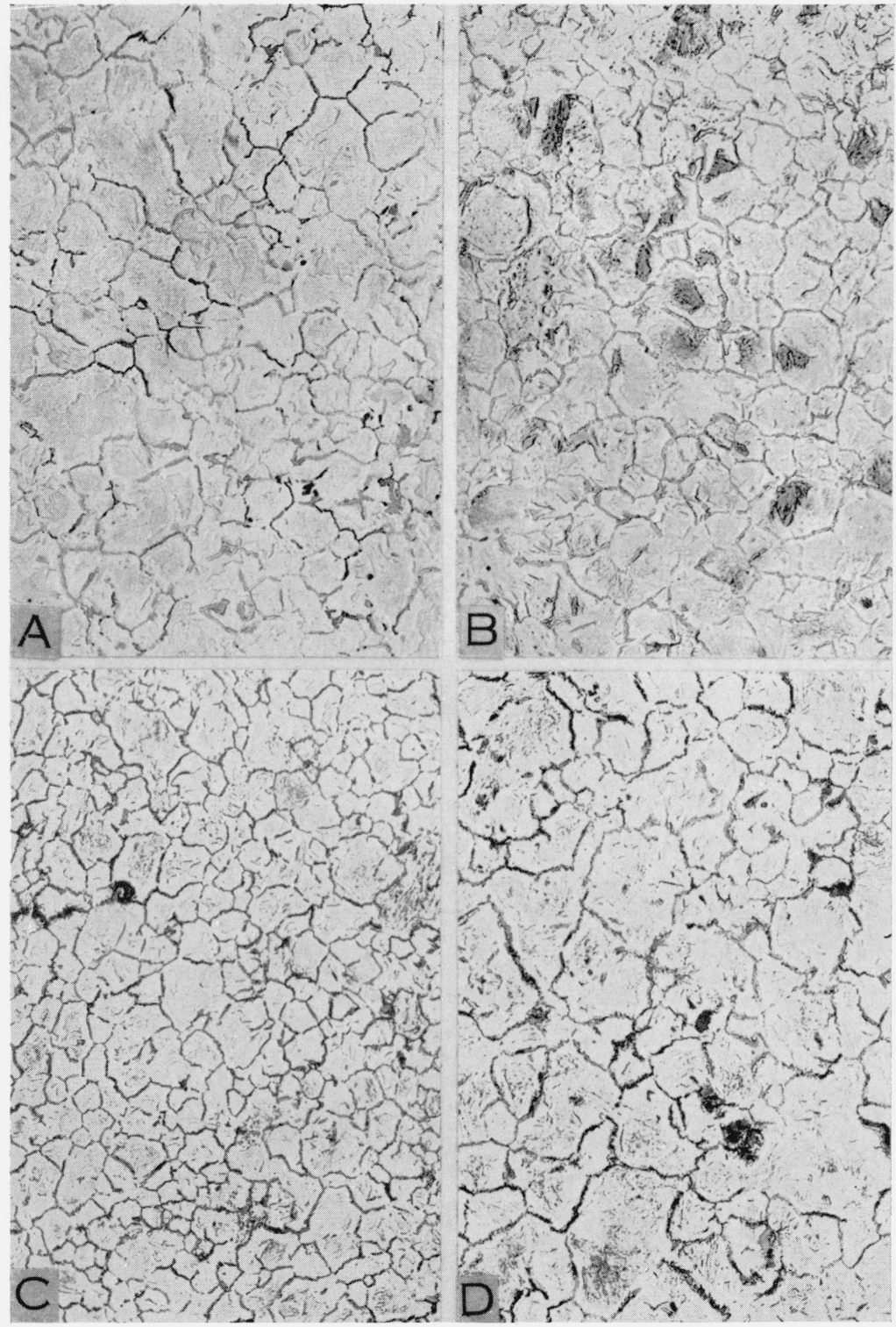

Figure 8.-Grain size at $1,600^{\circ} F$ of iron-carbon alloy HP-2 (1.01 percent of carbon).

$A$, Heated in lead bath; 20 grains per square inch at $\times 100 . \quad B$, Heated 625 degrees $\mathrm{F}$ per minute; 15 grains per square inch at $\times 100, C$, Heated 625 degrees $\mathbf{F}$ per minute; 40 grains per square inch at $\times 100, D$, Heated 13 degrees $F$ per minute; 11 grains per square inch at $\times 100$. Etched with boiling sodium-picrate solution. $\times 100$. 


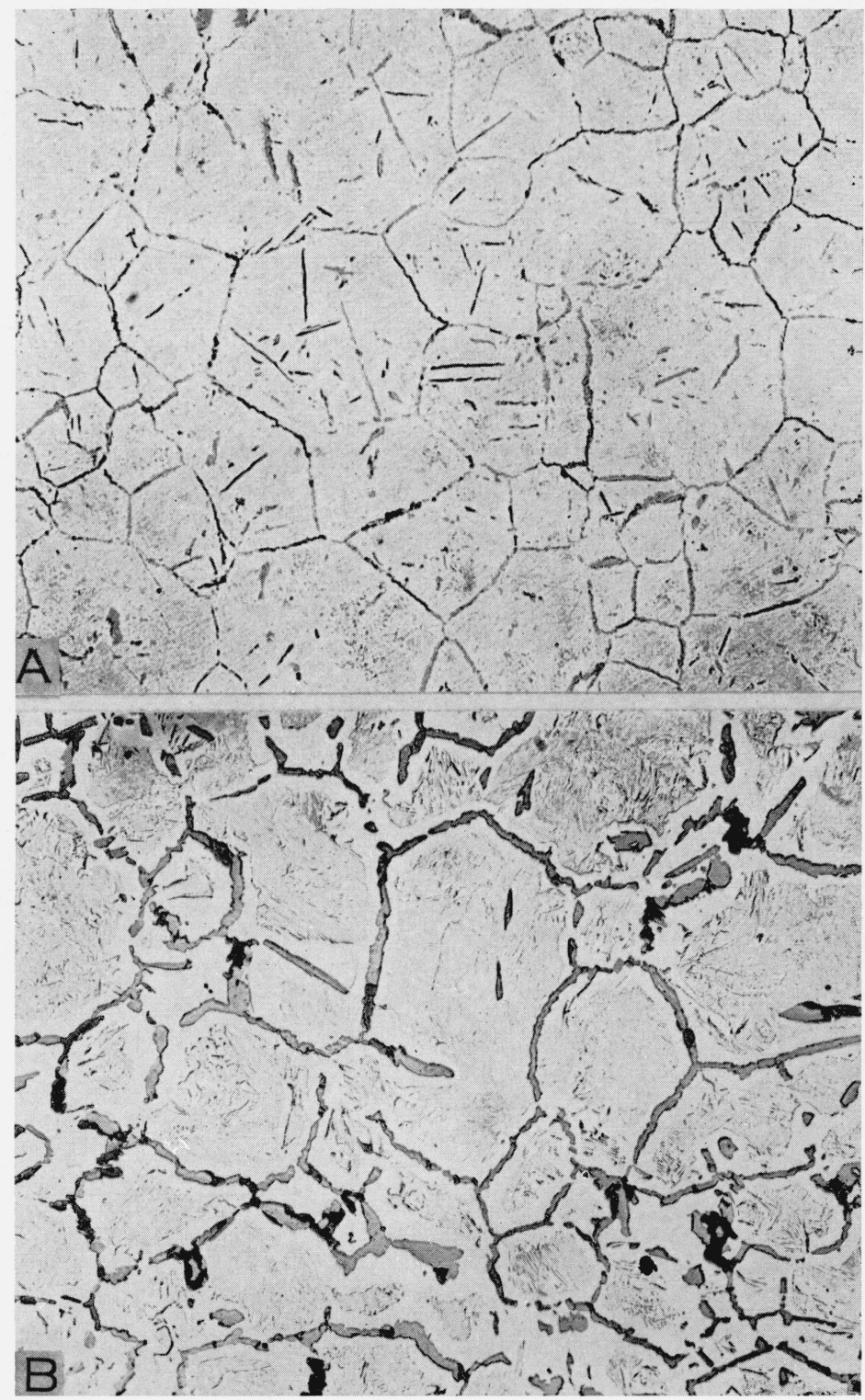

FiguRe 9.-Grain size at $1,800^{\circ} F$ of iron-carbon alloy HP-3 (1.21 percent of carbon).

$A$, Heated in lead bath; 5.3 grains per square inch at $\times 100$. $B$, Heated 3 degrees $\mathrm{F}$ per minute; 2.4 grains per square inch at $\times 100$. Etched with boiling sodium picrate solution. $\times 100$. 
by heating in vacuo at $1,700^{\circ} \mathrm{F}$. The hypoeutectoid steels had an initial structure of sorbite and ferrite (fig. $3, A$ and $C$ ), and the hypereutectoid steels had an initial structure of sorbite (fig. $3, B$ and $D$ ). The compositions of these steels are given in table 2 .

\section{RESULTS}

\section{HIGH-PURITY ALLOYS OF IRON AND CARBON}

In this group of alloys a comprehensive series of tests was made on the alloy containing 0.50 percent of carbon $(H P-1)$. The grain size of this alloy at $1,475^{\circ}, 1,500^{\circ}, 1,600^{\circ}$, and $1,800^{\circ} \mathrm{F}$ was determined for widely varying rates of heating through the transformation range. The grain size of the alloy containing 1.01 percent of carbon $(H P-2)$ was determined only at $1,600^{\circ} \mathrm{F}$ and that of the alloy containing 1.21 percent of carbon $(H P-3)$ was determined only at $1,800^{\circ} \mathrm{F}$, with various rates of heating. The results are summarized in tables 3,4 , and 5. Representative micrographs are reproduced in figures 4 to 9 , inclusive.

TABLE 3.-Grain size of iron-carbon alloy HP-1 (0.50 percent of carbon)

\begin{tabular}{|c|c|c|c|}
\hline $\begin{array}{l}\text { Temper- } \\
\text { ature }\end{array}$ & $\begin{array}{l}\text { Rate of } \\
\text { heating } \\
\text { between } \\
1,325^{\circ} \text { and } \\
1,450^{\circ} \mathrm{F}\end{array}$ & $\begin{array}{l}\text { Grains/in. }{ }^{2} \\
\text { at } \times 100\end{array}$ & Remarks \\
\hline${ }^{\circ} \mathrm{F}$ & $\begin{array}{l}\text { Degrees } \\
F / \text { min. }\end{array}$ & & \\
\hline $\begin{array}{l}1,475 \\
1,475\end{array}$ & $\begin{array}{l}\text { (1) } \\
\quad 7.7\end{array}$ & $\cdots$ & $\begin{array}{l}\text { Estimated ASTM grain No. } 7 . \\
\text { Estimated ASTM grain No. }-2 \text { to } 1 \text {. Grains not outlined in } \\
\text { approximately } 20 \text { percent of the area, which consisted of co- } \\
\text { alesced ferrite and pearlite. }\end{array}$ \\
\hline $\begin{array}{l}1,500 \\
1,500 \\
1,500 \\
1,500 \\
1,500 \\
1,500\end{array}$ & $\begin{array}{l}(1) \\
440 \\
200 \\
190 \\
170 \\
155\end{array}$ & $\begin{array}{l}35 \\
12 \\
4.3 \\
2.5 \\
3.5 \\
4.4\end{array}$ & 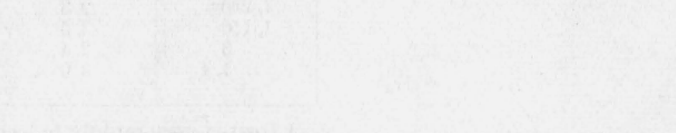 \\
\hline 1,500 & 13 & & $\begin{array}{l}\text { Estimated ASTM grain No. } 1 \text { or larger. Grains not outlined in } \\
\text { approximately } 30 \text { percent of the area, which consisted of co- } \\
\text { alesced ferrite and pearlite. }\end{array}$ \\
\hline 1,500 & 3 & & $\begin{array}{l}\text { Estimated ASTM grain No. } 1 \text { or larger. Grains not outlined in } \\
\text { approximately } 70 \text { per cent of the area, which consisted of co- } \\
\text { alesced ferrite and pearlite. }\end{array}$ \\
\hline $\begin{array}{l}1,600 \\
1,600 \\
1,600 \\
1,600 \\
1,600 \\
1,600 \\
1,600 \\
1,600 \\
1,600\end{array}$ & $\begin{array}{r}\left.{ }^{1}\right) \\
940 \\
470 \\
325 \\
280 \\
100 \\
80 \\
10 \\
3\end{array}$ & $\begin{array}{c}50 \\
12 \\
9 \\
9 \\
7.3 \\
1.2 \\
2.5 \\
0.4 \\
1.0\end{array}$ & \\
\hline $\begin{array}{l}1,800 \\
1,800 \\
1,800 \\
1,800 \\
1,800 \\
1,800 \\
1,800 \\
1,800\end{array}$ & $\begin{array}{r}(1) \\
1,875 \\
1,875 \\
1,365 \\
575 \\
415 \\
12 \\
11\end{array}$ & $\begin{array}{l}5.4 \\
3.0 \\
2.3 \\
5.2 \\
3.3 \\
4.9 \\
0.6\end{array}$ & Estimated ASTM grain No. 2. \\
\hline 1,800 & 3 & 1.0 & \\
\hline
\end{tabular}

${ }_{1}$ Heated very rapidly in lead bath. 
TABLE 4.-Grain size at $1,600^{\circ} \mathrm{F}$ of iron-carbon alloy $H P-2$ (1.01 percent of carbon)

\begin{tabular}{|c|c|c|}
\hline $\begin{array}{c}\text { Rate of Heat- } \\
\text { ing between } \\
1,325^{\circ} \text { and } \\
1,450^{\circ} \mathrm{F}\end{array}$ & $\begin{array}{l}\text { Grains/in. } .^{2} \\
\text { at } \times 100\end{array}$ & Remarks \\
\hline $\begin{array}{c}\text { Degrees } \\
\text { F/min } \\
\text { (1) } \\
\text { (1) } \\
1,070 \\
\\
830 \\
\\
625 \\
625 \\
625 \\
625 \\
580 \\
440 \\
420 \\
400 \\
13\end{array}$ & $\begin{array}{l}12 \\
11 \\
15 \\
40 \\
12 \\
10\end{array}$ & $\begin{array}{l}\text { Mixed grains-estimated } 10 \text { percent of ASTM grain No. } 3 \\
\text { to } 4 \text { and } 90 \text { percent of No. } 7 \text { to } 8 \text {. } \\
\text { Mixed grains-estimated } 10 \text { percent of ASTM grain No. } 3 \text { to } \\
4 \text { and } 90 \text { percent of No. } 7 \text { to } 8 \text {. } \\
\text { Mixed-noted all grains from ASTM grain No. } 2 \text { to } 7 \text {. Few } \\
\text { No. } 2 \text { to } 3 \text {, majority No. } 5 \text {. } \\
\text { Estimated ASTM grain No. } 4 \text { to } 5 \text {. }\end{array}$ \\
\hline
\end{tabular}

1 Heated very rapidly in lead bath.

TABLE 5.-Grain size at $1,800^{\circ} \mathrm{F}$ of iron-carbon alloy $H P-3$ (1.21 percent of carbon)

\begin{tabular}{|c|c|}
\hline $\begin{array}{c}\text { Rate of Heat- } \\
\text { ing between } \\
1,325^{\circ} \text { and } \\
1,450^{\circ} \mathrm{F}\end{array}$ & $\begin{array}{c}\text { Grains/in.2 } \\
\text { at } \times 100\end{array}$ \\
\hline $\begin{array}{c}\text { Degrees F/min } \\
(1)\end{array}$ & \\
1,875 & 5.3 \\
1,670 & 3.2 \\
1,670 & 2.8 \\
1,670 & 2.7 \\
1,360 & 3.1 \\
1,250 & 3.7 \\
1,250 & 2.0 \\
1,150 & 2.3 \\
3 & 3.5 \\
1.4 & 2.4 \\
& 3.0 \\
\hline
\end{tabular}
bath.

Heated very rapidly in lead

With the 0.50-percent-carbon alloy, the rate of heating through the transformation range had a very marked effect upon the grain size at all temperatures investigated below $1,800^{\circ} \mathrm{F}$. The grain size increased with decrease in rate of heating. This trend was most pronounced in the upper range of heating rates - that is, after the rate of heating had decreased to a certain value, further decrease in rate caused but little increase in grain size of this alloy. At $1,800^{\circ} \mathrm{F}$, coarse grains (ASTM grain No. 1 to 3 ) were produced regardless of the rate of heating through the transformation range. It should be pointed out, however, that the trend of increase in grain size with decrease in rate of heating also existed for the specimens heated at $1,800^{\circ} \mathrm{F}$. 
With slow rates of heating, coarse grains of the same order of magnitude were obtained at all temperatures. However, considerably coarser grains were produced at $1,475^{\circ}, 1,500^{\circ}$, and $1,600^{\circ} \mathrm{F}$ with slow rates of heating than at $1,800^{\circ} \mathrm{F}$ with fast rates of heating.

The coarse grains produced at $1,475^{\circ}$ and $1,500^{\circ} \mathrm{F}$ in the 0.50 percent-carbon alloy with relatively slow rates of heating were found, upon cooling, to be associated with areas containing numerous ferrite and pearlite islands (figs. $4, B$, and $5, D$ ). The appearance, however, suggested that these were originally not mixed austenitic grains but that some of the large grains of the parent austenite had broken into many small grains of ferrite and pearlite. At $1,500^{\circ} \mathrm{F}$, this condition was noticeable for the specimen heated at the rate of 13 degrees $\mathrm{F} / \mathrm{min}$ (table 3 and fig. $5, D$ ); for the specimen heated at the still slower rate of 3 degrees $\mathrm{F} / \mathrm{min}$, this condition was considerably more marked. With slow rates of heating, specimens heated to 1,600 and $1,800^{\circ} \mathrm{F}$ were also coarse grained, but coalescence of ferrite and pearlite was not observed.

The results obtained for the 1.01-percent-carbon alloy at $1,600^{\circ} \mathrm{F}$ (table 4 and fig. 8) showed that the finest grains were not obtained with the most rapid heating. For example, approximately 20 grains per square inch at 100 diameters (ASTM grain No. 5) were produced in the specimens heated rapidly in a lead bath, whereas mixed grains, estimated as 10 percent of ASTM grain No. 3 to 4 and 90 percent of No. 7 to 8 (not shown in fig. 8), were produced by decreasing the heating rate to about 1,000 degrees $\mathrm{F} / \mathrm{min}$. Furthermore, there was an appreciable scatter in values of the grain sizes obtained when the rates were approximately constant and of the order of 625 degrees $\mathrm{F} / \mathrm{min}$ (fig. 8, $B$ and $C$ ). These results suggest the possibility of the existence of a critical rate of heating through the transformation range that produces austenitic grains of minimum size. That is, larger grains may be produced when the heating rate is either faster or slower than the critical value.

The rate of heating through the transformation range had little effect on the grain size, established at $1,800^{\circ} \mathrm{F}$, of the iron-carbon alloy containing 1.21 percent of carbon (table 5 and fig. 9 ).

The final austenitic grain size of these high-purity alloys of iron and carbon was influenced by the rate of heating through the transformation range and by the maximum temperature to which the alloys were heated.

\section{COMMERCIAL PLAIN CARBON STEELS}

It was believed that the general relation between rate of heating and grain size of commercial steels could be established by securing data on the effect of rate of heating on two hypoeutectoid and two hypereutectoid steels, one of which in each case had been treated to produce what is usually termed a "controlled" steel. The results obtained are summarized in tables $6,7,8$, and 9. Representative micrographs of the grain sizes at different temperatures with various rates of heating are shown in figures 10 to 13 , inclusive. 
TABLE 6.-Grain size of steel $C-1(0.49$ percent of carbon, noncontrolled)

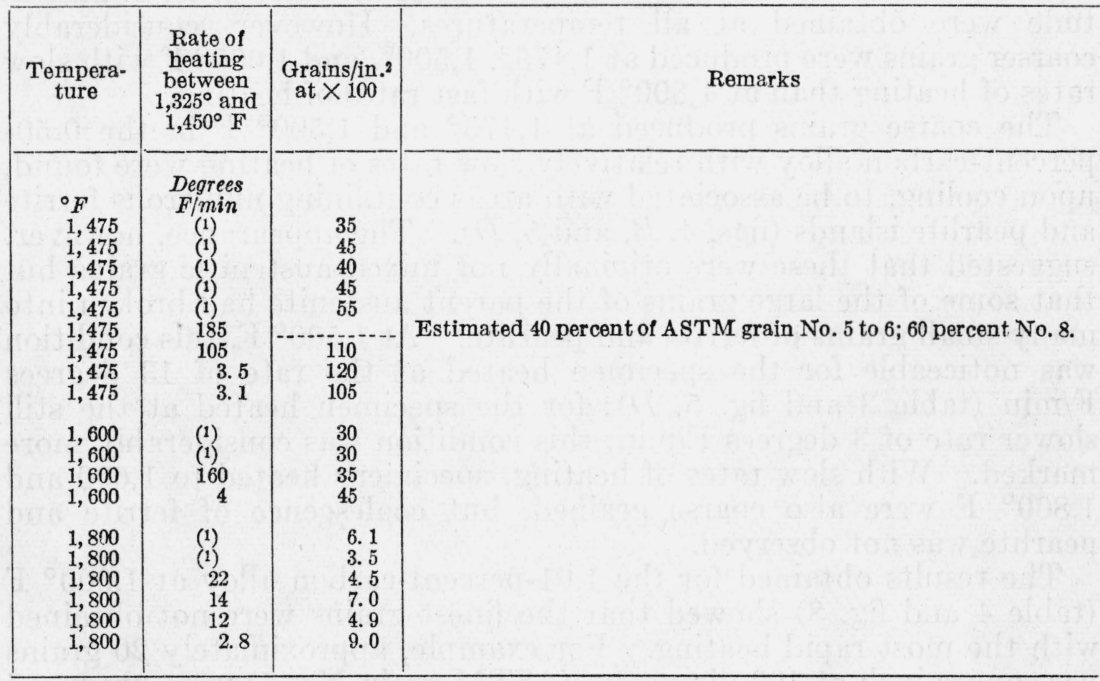

1 Heated very rapidly in lead bath.

TABLE 7.-Grain size of steel C-2 (0.49 percent of carbon, controlled)

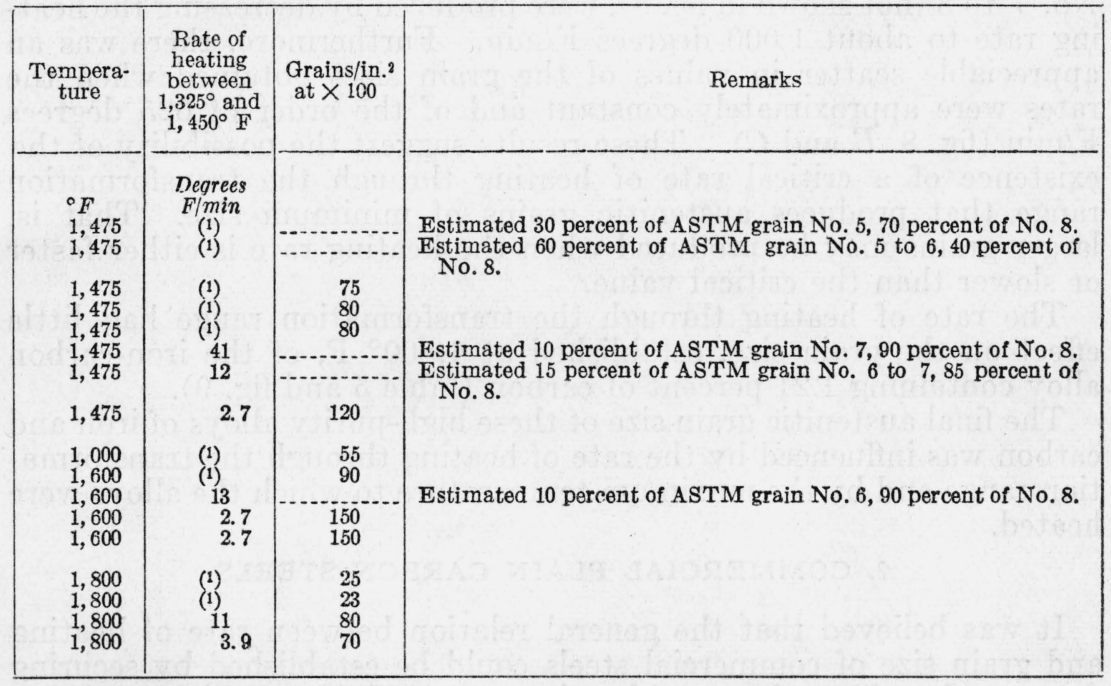

1 Heated very rapidly in lead bath. 

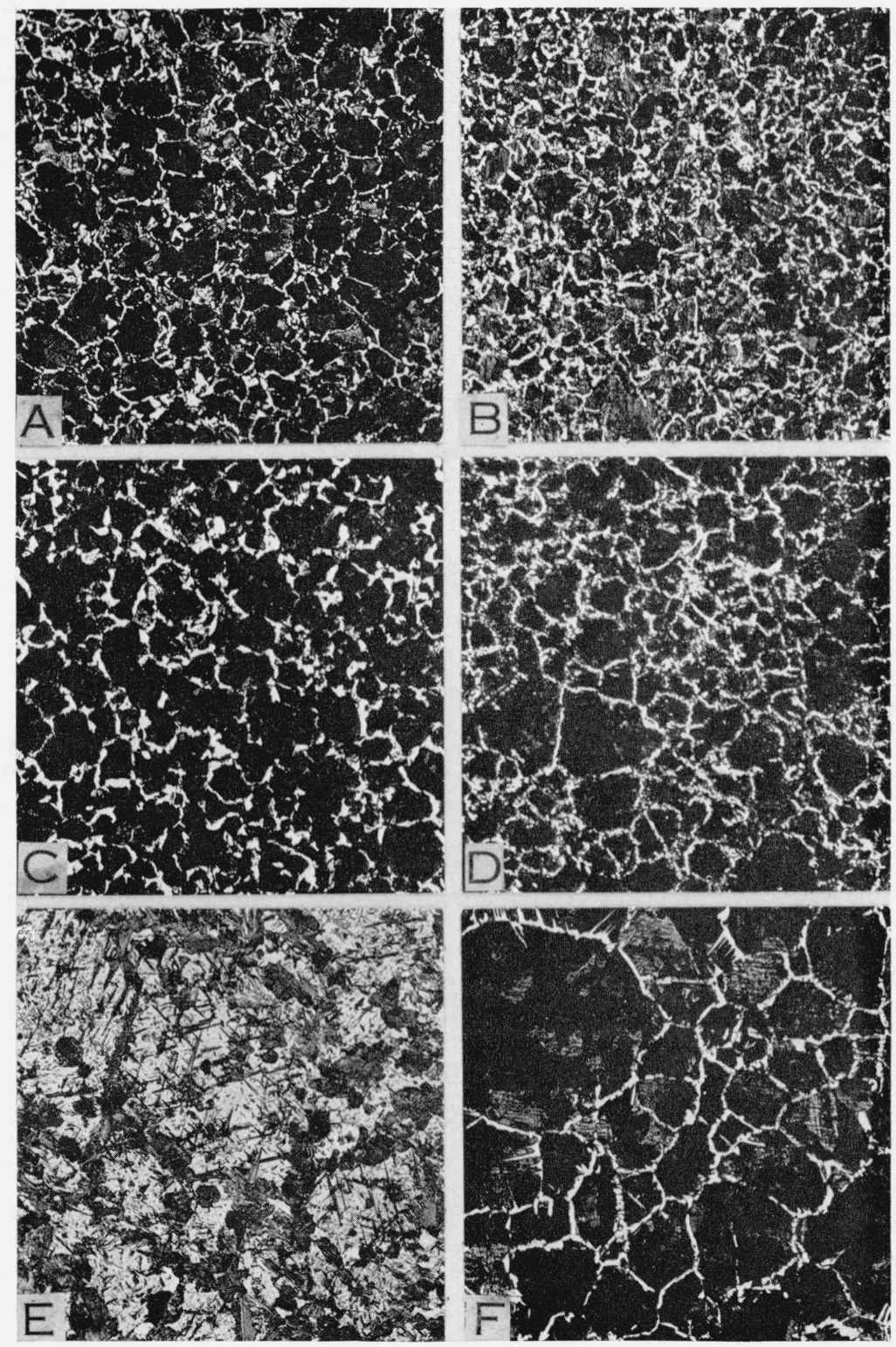

Figure 10.-Grain size at different temperatures of commercial steel $C-1 \quad(0.49$ percent of carbon, noncontrolled grain size).

$A, 1,475^{\circ} \mathrm{F}$; heated in lead bath; 35 grains per square inch at $\times 100, B, 1,475^{\circ} \mathrm{F}$; heated 3.1 degrees $\mathrm{F}$ per minute; 105 grains per square inch at $\times 100 . \quad C, 1,600^{\circ} \mathrm{F}$; heated in lead bath; 30 grains per square inch at $\times 100 . \quad D, 1,600^{\circ} \mathrm{F}$; heated 4 degrees $\mathrm{F}$ per minute; 45 grains per square inch at $\times 100 . \quad E, 1,800^{\circ} \mathrm{F}$; heated in lead bath; 6.1 grains per square inch at $\times 100 . \quad F, 1,800^{\circ} \mathrm{F}$; heated 2.8 degrees $\mathrm{F}$ per minute; 9 grains per

square inch at $\times 100$. Etched with 1-percent nital. $\times 100$ 

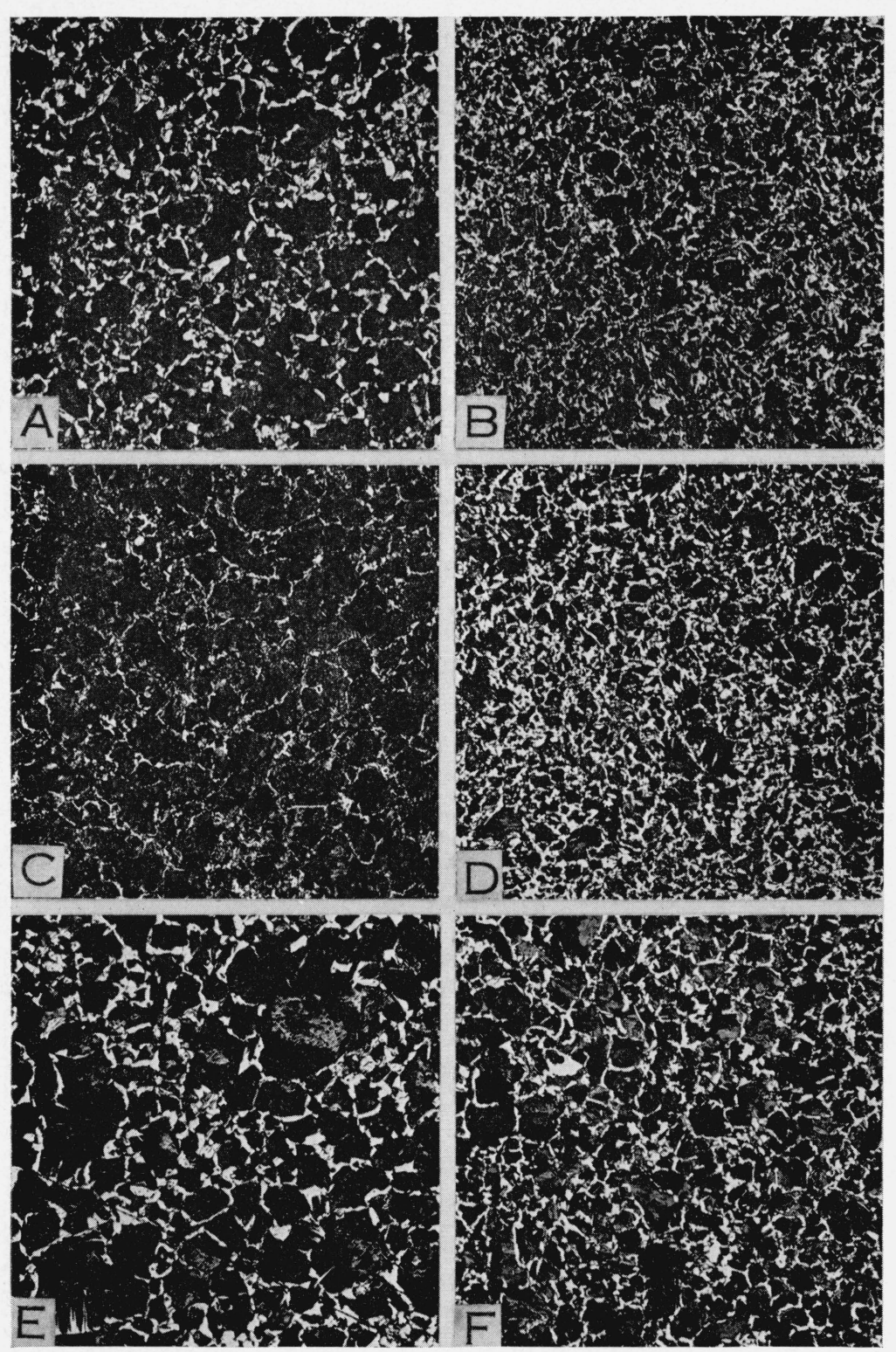

FIGURE 11.-Grain size at different temperatures of commercial steel C-2 (0.49 percent of carbon, controlled grain size).

$A, 1,475^{\circ} \mathrm{F}$; heated in lead bath; 80 grains per square inch at $\times 100 . \quad B, 1,475^{\circ} \mathrm{F}$; heated 2.7 degrees $\mathrm{F}$ per minute; 120 grains per square inch at $\times 100 . C, 1,600^{\circ} \mathrm{F}$; heated in lead bath; 55 grains per square inch at $\times 100$. $D, 1,600^{\circ} \mathrm{F}$; heated 2.7 degrees $\mathrm{F}$ per minute; 150 grains per square inch at $\times 100.2 \mathrm{E}, 1,800^{\circ} \mathrm{F}$; heated in lead bath; 25 grains per square inch at $\times 100 . \quad F, 1,800^{\circ} \mathrm{F}$; heated 3.9 degrees $\mathrm{F}$ per minute; 70 grains per square inch at $\times 100$. Etched with 1-percent nital. $\times 100$. 


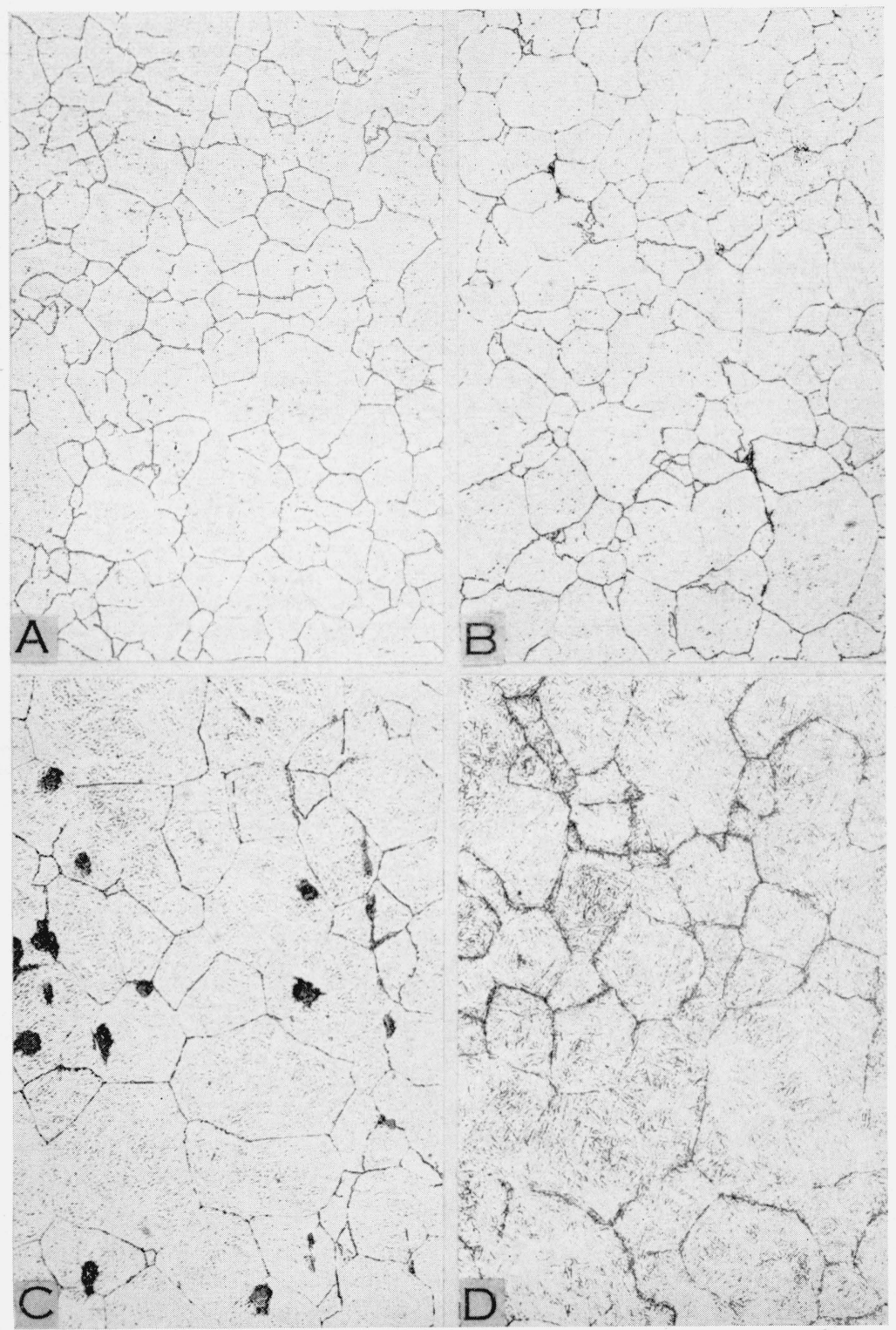

FiguRE 12.-Grain size at different temperatures of commercial steel C-3 (1.05 percent of carbon, noncontrolled grain size).

$A, 1,650^{\circ} \mathrm{F}$; heated in lead bath; 20 grains per square inch at $\times 100 . B, 1,650^{\circ} \mathrm{F}$; heated 3 degrees $\mathrm{F}$ per minute; 16 grains per square inch at $\times 100 . C, 1,800^{\circ} \mathrm{F}$; heated in lead bath; 5.3 grains per square inch at $\times 100$. $D, 1,800^{\circ} \mathrm{F}$; heated 3.6 degrees $\mathrm{F}$ per minute; 5.9 grains per square inch at $\times 100$. Etched with 1 percent nital. $\times 100$ 

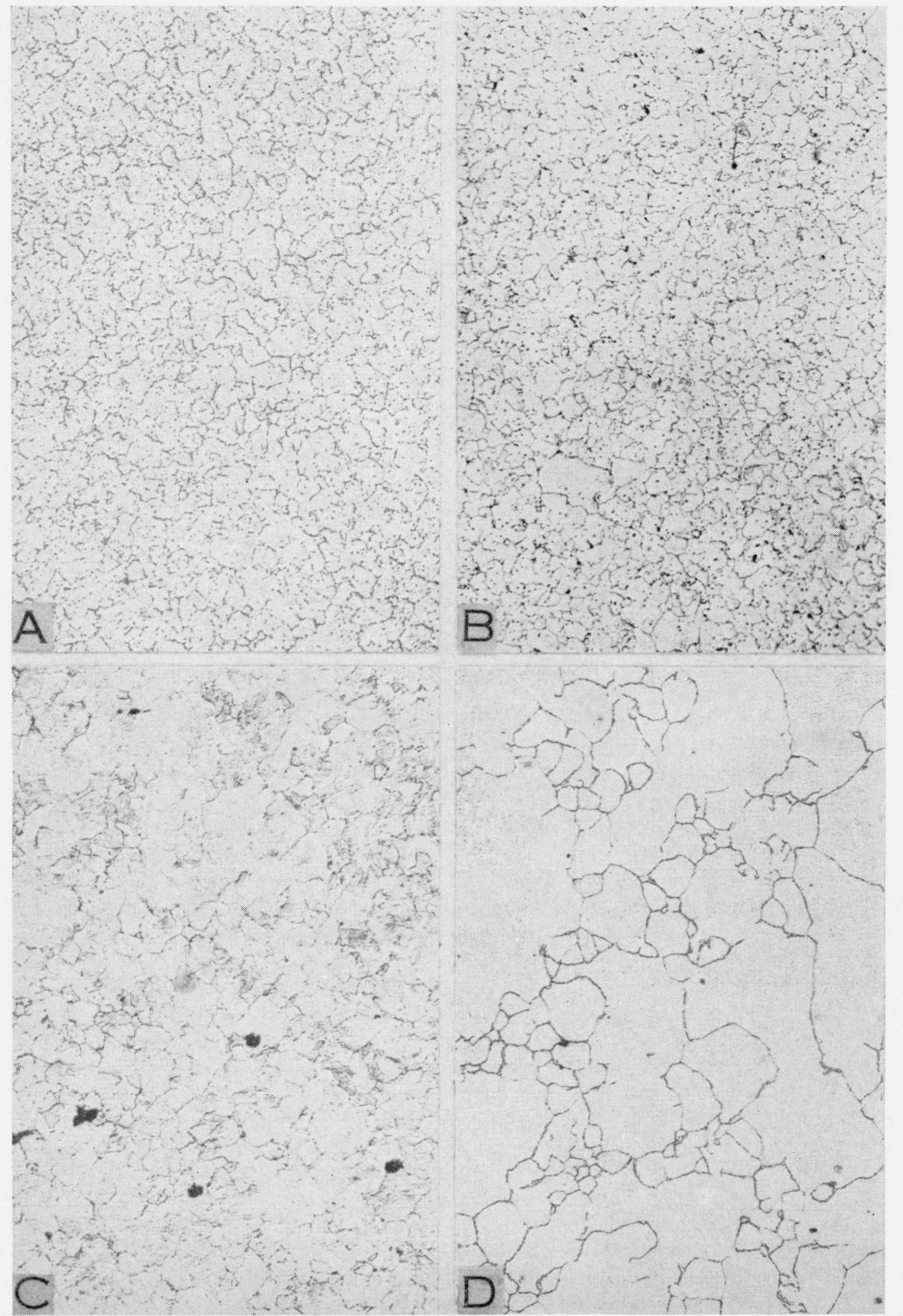

FIGURE 13.-Grain size at different temperatures of commercial steel C-4 (1.06 percent of carbon, controlled grain size).

$A, 1,650^{\circ} \mathrm{F}$; heated in lead bath; 90 grains per square inch at $\times 100$; etched with 1-percent nital. $\times 100 ., B$, $1,650^{\circ} \mathrm{F}$; heated 9 degrees $\mathrm{F}$ per minute; 110 grains per square inch at $\times 100$; etched with boiling sodium picrate, $\times 100, C, 1,800^{\circ} \mathrm{F}$; heated in lead bath; 95 grains per square inch at $\times 100$; etched with boiling sodium picrate and 1-percent nital. $\times 100 . D, 1,800^{\circ} \mathrm{F}$; heated 2.8 degrees $\mathrm{F}$ per minute; estimated 25 percent of ASTM grain No. 7, 25 percent of No. 4, and 50 percent of No. 1; etched with 1-percent nital. $\times 100$. 
TABLE 8.-Grain size of steel C-3 (1.05 percent of carbon, noncontrolled)

\begin{tabular}{|c|c|c|}
\hline Temperature & $\begin{array}{c}\text { Rate of heating } \\
\text { between } 1,325^{\circ} \\
\text { and } 1,450^{\circ} \mathrm{F}\end{array}$ & $\begin{array}{c}\text { Grains/in.2 } \\
\text { at } \times 100\end{array}$ \\
\hline & $\begin{array}{c}\text { D } F \\
1,650\end{array}$ & $\begin{array}{c}\text { Degrees } F / \min \\
(1)\end{array}$ \\
1,650 & 750 & 20 \\
1,650 & 9 & 26 \\
1,650 & 3 & 18 \\
1,800 & $(1)$ & 5.3 \\
1,800 & $(1)$ & 4.9 \\
1,800 & 9 & 5.2 \\
1,800 & 3.6 & 5.9 \\
\hline
\end{tabular}

1 Heated very rapidly in lead bath.

TABLE 9.-Grain size of steel C-4 (1.06 percent of carbon, controlled)

\begin{tabular}{|c|c|c|c|}
\hline $\begin{array}{c}\text { Tempera- } \\
\text { ture }\end{array}$ & $\begin{array}{l}\text { Rate of } \\
\text { heating } \\
\text { between } \\
1,325^{\circ} \text { and } \\
1,450^{\circ} \mathrm{F}\end{array}$ & $\begin{array}{l}\text { Grains/in. }{ }^{2} \\
\text { at } \times 100\end{array}$ & Remarks \\
\hline $\begin{array}{l}{ }^{\circ} \mathrm{F} \\
1,650 \\
1,650 \\
1,650 \\
1,650\end{array}$ & $\begin{array}{c}\text { Degrees } \\
F / \min \\
(1) \\
(1) \\
940 \\
9\end{array}$ & $\begin{array}{r}90 \\
85 \\
40 \\
110\end{array}$ & \multirow{3}{*}{$\begin{array}{l}\text { Estimated } 25 \text { percent of ASTM grain No. } 6 \text { to } 8,15 \\
\text { percent of No. } 4 \text { to } 5,60 \text { percent of No. } 1 \text { or larger. } \\
\text { Estimated } 25 \text { percent of ASTM grain No. } 7,25 \text { percent } \\
\text { of No. } 4,50 \text { percent of No.1. }\end{array}$} \\
\hline $\begin{array}{l}1,800 \\
1,800 \\
1,800 \\
1,800\end{array}$ & $\begin{array}{l}(1) \\
(1) \\
9 \\
8.6\end{array}$ & $\begin{array}{l}95 \\
95 \\
13\end{array}$ & \\
\hline 1,800 & 2.8 & & \\
\hline
\end{tabular}

1 Heated very rapidly in lead bath.

The rate of heating through the transformation range influenced the grain size established at $1,475^{\circ} \mathrm{F}$ (recommended hardening temperature) of the hypoeutectoid steels with both "noncontrolled" and "controlled" grain size (Figs. 10, $A$ and $B$, and $11, A$ and $B$ ) and at $1,600^{\circ}$ and $1,800^{\circ} \mathrm{F}$ of the controlled steel (Fig. 11, $C, D, E$, and $F$ ). The rate of heating had no appreciable effect on the grain size at $1,600^{\circ}$ and $1,800^{\circ} \mathrm{F}$ of the noncontrolled steel (Fig. 10, $C, D$, $E$, and $F$ ). Regardless of the rate of heating, both of these steels were fine-grained at $1,475^{\circ} \mathrm{F}$, and the controlled steel was finegrained at $1,600^{\circ} \mathrm{F}$.

Under conditions in which the grain size was influenced by the rate of heating these commercial 0.49-percent-carbon steels, the minimum-sized grains were not obtained with the maximum rate of heating. That is, in these steels the grain size tended to increase with increase in rate of heating. This trend is contrary to that observed in the high-purity alloy of iron and carbon having a similar carbon content.

The rate of heating had no significant effect on the grain size at $1,650^{\circ}$ and $1,800^{\circ} \mathrm{F}$ of the noncontrolled steel containing 1.05 percent of carbon (table 8 and fig. 12). With the controlled steel, the rate of heating influenced the grain size at both $1,650^{\circ}$ and $1,800^{\circ} \mathrm{F}$. At the lower temperature, the coarsest grains were obtained with an intermediate rate of heating (table 9). Slow rates of heating pro- 
duced grains of the same order of magnitude as very rapid rates (fig. 13, $A$ and $B$ ). At $1,800^{\circ} \mathrm{F}$, the grain size of this steel increased with decrease in rate of heating (fig. 13, $C$ and $D$ ), a trend similar to that shown by the 0.50 -percent-carbon alloy and contrary to that of the commercial hypoeutectoid steels.

These results obtained with commercial plain carbon steels, both noncontrolled and controlled, show that in certain heats the austenitic grain sizes established at various temperatures were sensitive to the rate of heating through the transformation range. In other heats, the grain sizes were insensitive to the rate of heating. The cause of the observed variations cannot be definitely stated at this time.

\section{EXPERIMENTAL PLAIN CARBON STEELS}

It is apparent that the effect of rate of heating on the grain size of the iron-carbon alloys was different from the effect on commercial plain carbon steels. Since the preparation of the iron-carbon alloys was different from that of the commercial steels, it was thought that the procedure used in preparing the alloys might have had some influence on the relation between the heating rate and grain size. Specimens were available of both hypoeutectoid and hypereutectoid steels prepared from a 0.2-percent-carbon steel (aluminum-killed) by pack-carburizing and by gas-carburizing, as described in a previous section of this report. If the method of introduction of carbon (gascarburizing) were responsible for the differences observed in the grain sizes of the iron-carbon alloys with various rates of heating, it was thought that perhaps a similar relation would be shown in the carburized steels.

The grain size established at $1,600^{\circ} \mathrm{F}$ with various rates of heating was determined for the experimental steels containing about 0.5 and 1 percent of carbon. The results of the grain-size measurements are summarized in table 10 . These data and the representative micrographs (figs. 14 and 15) show that the rate of heating had no significant effect on the grain size at $1,600^{\circ} \mathrm{F}$ of any of these steels.

The results obtained with the experimental steels indicate that the variations in grain size with rate of heating of the high-purity alloys of iron and carbon cannot be attributed solely to the method by which carbon was introduced.

TABLE 10.-Grain size at $1,600^{\circ} \mathrm{F}$ of experimental steels

\begin{tabular}{|c|c|c|c|}
\hline Steel & $\begin{array}{c}\text { Rate of } \\
\text { heating } \\
\text { between } \\
1,325^{\circ} \text { and } \\
1,450^{\circ} \mathrm{F}\end{array}$ & $\begin{array}{c}\text { Grains/in. }{ }^{2} \\
\text { at } \times 100\end{array}$ & Remarks \\
\hline $\begin{array}{r}P C-1(0.48 \% \mathrm{C}) \\
\text { Do } \\
P C-2(1.12 \% \mathrm{C}) \\
\text { Do } \\
\text { Do.. } \\
\text { Do } \\
G C-1(0.57 \% \mathrm{C}) \\
\text { Do } \\
G C-2(1.02 \% \mathrm{C}) \\
\text { Do } \\
\text { Do }\end{array}$ & 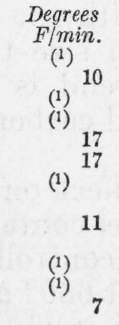 & $\begin{array}{r}45 \\
15 \\
16 \\
16 \\
14 \\
11 \\
11\end{array}$ & $\begin{array}{l}\text { Estimated } 15 \text { percent of ASTM grain No. } 2 \text { to } 3 \text {, } \\
15 \text { percent of No. } 4,70 \text { percent of No. } 7 \text { to } 8 \text {. } \\
\text { Few ASTM grain No. } 2 \text { to } 3 \text { and } 7 \text {. } \\
\text { Do. } \\
\text { Estimated ASTM grain No. } 4 \text {. } \\
\text { Estimated about } 60 \text { percent of ASTM grain No. } \\
2 \text { to } 4,40 \text { percent of No. } 7 \text { to } 8 \text {. } \\
\text { Estimated } 50 \text { percent ASTM grain No. } 2 \text { to } 4 \text {, } \\
50 \text { percent of No. } 7 \text { to } 8 \text {. }\end{array}$ \\
\hline
\end{tabular}

1 Heated very rapidly in lead bath. 

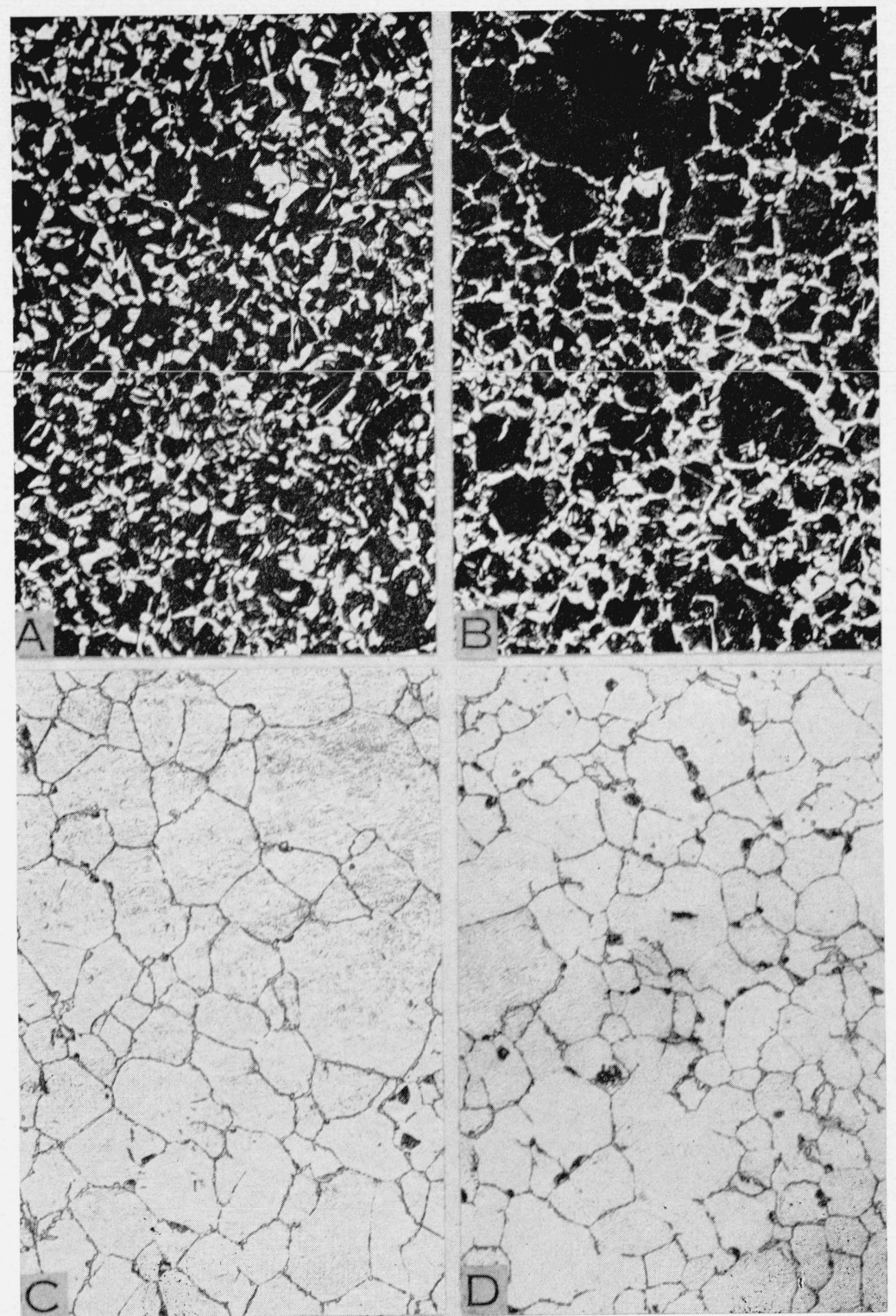

Figure 14.-Grain size at $1,600^{\circ} F$ of experimental plain carbon steels (pack carburized).

A, $P C-1$ (0.48 percent of carbon); heated in lead bath; 45 grains per square inch at $\times 100 . \quad B, P C-1(0.43$ percent of carbon); heated 10 degrees $\mathrm{F}$ per minute; estimated 15 percent of ASTM grain No. 2 to 3,15 percent of No. 4, and 70 percent of No. 7 to 8 . C, PC-2 (1.12 percent of carbon); heated in lead bath: 15 grains per square inch at $\times 100 . \quad D, P C-2$ (1.12 percent of carbon); heated 17 degrees $\mathrm{F}$ per minute; 16 grains per square inch at $\times 100$. Etched with 1-percent nital. $\times 100$. 


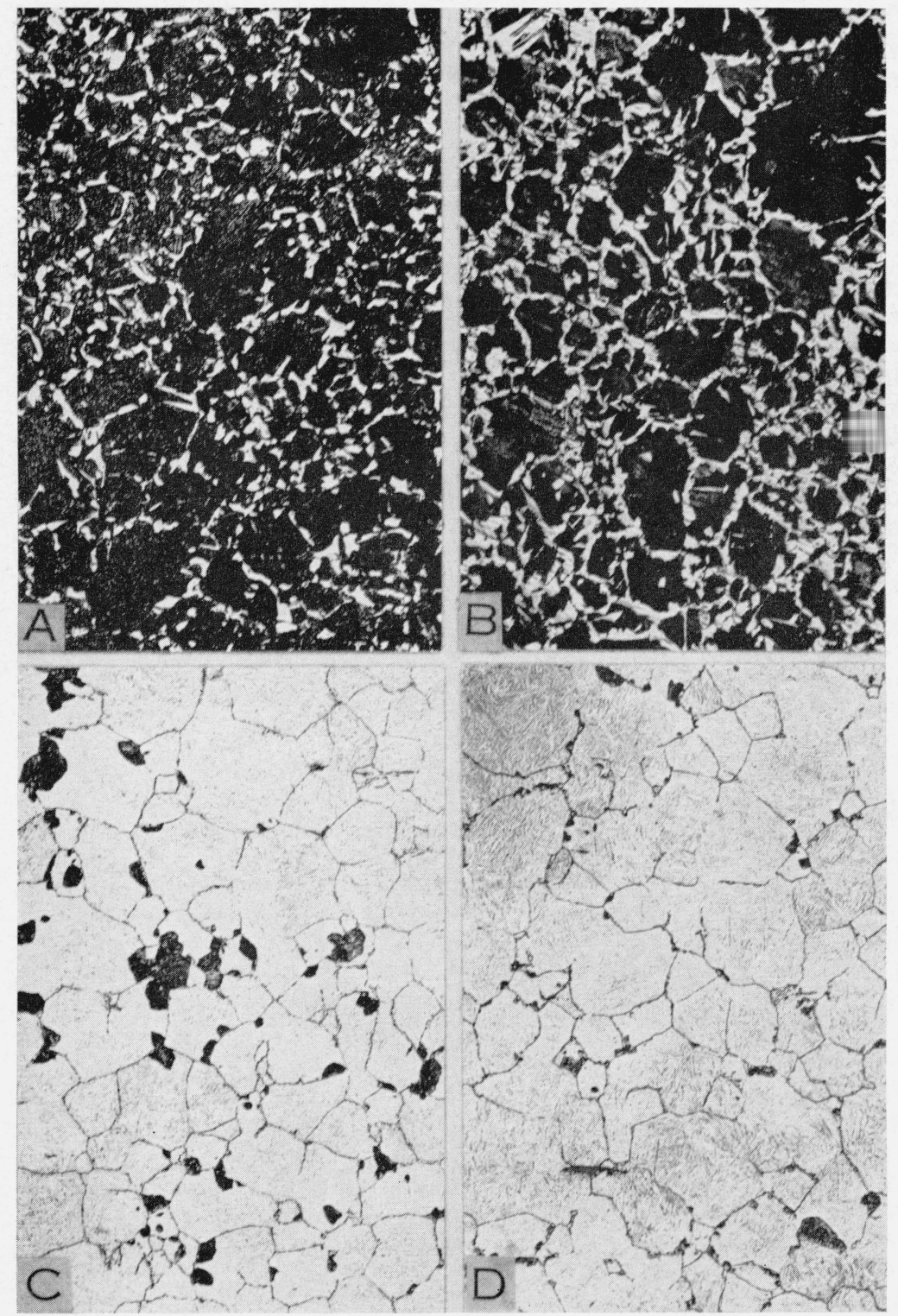

FIGURE 15.-Grain size at $1,600^{\circ} \mathrm{F}$ of experimental plain carbon steels (gas carburized).

A, GC-1 (0.57 percent of carbon); heated in lead bath; estimated 60 percent of ASTM grain No. 2 to 4,40 percent of No. 7 to 8 . $B, G C-1$ ( 0.57 percent of carbon); heated 11 degrees $\mathrm{F}$ per minute: estimated 50 percent of ASTM grain No. 2 to 4, 50 percent of No. 7 to 8. C, GC-2 (1.02 percent of carbon); heated in lead bath; 14 grains per square inch at $\times 100 . \quad D, G C-2$ (1.02 percent of carbon); heated 7 degrees $\mathrm{F}$ per minute; 11 grains per square inch at $\times 100$. Etched with 1-percent nital. $\times 100$. 


\section{SUMMARY}

The austenitic grain size established at different temperatures with various rates of heating through the transformation range was determined for high-purity alloys of iron and carbon, and for commercial and experimental steels which had a wide range in carbon content. The commercial steels also differed in the method of deoxidation.

For the high-purity alloys of iron and carbon containing 0.50 percent of carbon, the grain size at $1,475^{\circ}, 1,500^{\circ}$, and $1600^{\circ} \mathrm{F}$ increased with decrease in rate of heating, whereas the grain size at $1,800^{\circ} \mathrm{F}$ was not so noticeably dependent upon the rate of heating. Coarser grains were produced at the lower temperatures with slow rates of heating than at higher temperatures with fast rates of heating. With slow rates of heating, grains of the same order of magnitude (coarse grains) were obtained at all temperatures.

With the high-purity alloy of iron and carbon containing 1.01 percent of carbon, the grain size at $1,600^{\circ} \mathrm{F}$ increased but slightly with decrease in rate of heating. There were indications that for this alloy there is a critical rate of heating at which rate the finest grains were obtained.

With the high-purity alloy of iron and carbon containing 1.21 percent of carbon, the rate of heating had no significant effect on the grain size at $1,800^{\circ} \mathrm{F}$.

The rate of heating influenced the grain size at $1,475^{\circ} \mathrm{F}$ of the commercial 0.49-percent-carbon steels with both noncontrolled and controlled grain size, and at $1,600^{\circ}$ and $1,800^{\circ} \mathrm{F}$ of the noncontrolled steel. The grain size of these steels tended to increase with increase in rate of heating.

With the noncontrolled steel containing 1.05 percent of carbon, the rate of heating had no significant effect on the grain size at $1,650^{\circ}$ and $1,800^{\circ} \mathrm{F}$. With the controlled steel of similar carbon content, the grain size at $1,650^{\circ}$ and $1,800^{\circ} \mathrm{F}$ was influenced by the rate of heating. At the lower temperature, the coarsest grains were produced with an intermediate rate of heating, whereas at the higher temperature the coarsest grains were produced with the slowest rate of heating.

With the experimental steels, containing approximately 0.5 and 1 percent of carbon, the grain size at $1,600^{\circ} \mathrm{F}$ was not affected by the rate of heating.

The data presented in this report show that, in certain cases, the austenitic grain size of high-purity alloys of iron and carbon and plain carbon steels is affected by the rate of heating through the transformation range; that is, the grain size of some of these materials is sensitive to the rate of heating. All the materials, however, did not respond in the same manner. In view of these findings it is necessary, when making grain-size specifications, that consideration be given to the possible effects that the rate of heating through the transformation range may have upon the grain size of the steels under consideration. 


\section{REFERENCES}

[1] T. G. Digges, Influence of austenitic grain size on the critical cooling rate of high-purity iron-carbon alloys, J. Research NBS 21, 723 (1940) RP1308.

[2] N. F. Ward and J. E. Dorn, Grain size of steel-a critical review, Metals \& Alloys 10, 74, 115, 212, 246 (1939).

[3] Carl Shapiro, What about grain size?, Iron Age 143, 25, March 16; 23, March 30; 33, April 6 (1939).

[4] M. A. Grossmann, Grain size in metals, with particular reference to grain growth in austenite, Trans. Am. Soc. Metals 22, 861 (1934).

[5] T. G. Digges and Louis Jordan, Hardening characteristics and other properties of commercial ore-percent-carbon tool steels, J. Research NBS 15, 385 (1935) RP837. Also, Hardening characteristics of one-percent-carbon tool steels, Trans. Am. Soc. Metals 23, 839 (1935).

[6] H. Tobin and R. L. Kenyon, Austenitic grain size of eutectoid steel, Trans. Am. Soc. Metals 26, 133 (1938).

[7] C. H. Herty, Jr., D. L. McBride, and S. O. Hough, The effect of deoxidation on grain size and grain growth in plain carbon steels, Cooperative Bulletin 65, Mining and Met. Investigations, U. S. Bur. Mines, Carnegie Inst. Tech. Mining Met. Advisory Boards (1934).

[8] T. G. Digges, Effect of carbon on the critical cooling rate of high-purity ironcarbon alloys and plain carbon steels, J. Research NBS 20, 571 (1938) RP1092. Also, Effect of carbon on the hardenability of high-purity iron-carbon alloys, Trans. Am. Soc. Metals 26, 408 (1938).

Washington, May 27, 1940. 